\title{
Biochemical characteristics and synergistic effect of two novel alginate lyases from Photobacterium sp. FC615
}

Danrong Lu, Qingdong Zhang, Shumin Wang, Jingwen Guan, Runmiao Jiao, Naihan Han, Wenjun Han and Fuchuan Li*

\begin{abstract}
Background: Macroalgae and microalgae, as feedstocks for third-generation biofuel, possess competitive strengths in terms of cost, technology and economics. The most important compound in brown macroalgae is alginate, and the synergistic effect of endolytic and exolytic alginate lyases plays a crucial role in the saccharification process of transforming alginate into biofuel. However, there are few studies on the synergistic effect of endolytic and exolytic alginate lyases, especially those from the same bacterial strain.
\end{abstract}

Results: In this study, the endolytic alginate lyase AlyPB1 and exolytic alginate lyase AlyPB2 were identified from the marine bacterium Photobacterium sp. FC615. These two enzymes showed quite different and novel enzymatic properties whereas behaved a strong synergistic effect on the saccharification of alginate. Compared to that when AlyPB2 was used alone, the conversion rate of alginate polysaccharides to unsaturated monosaccharides when AlyPB1 and AlyPB2 acted on alginate together was dramatically increased approximately sevenfold. Furthermore, we found that AlyPB1 and AlyPB2 acted the synergistic effect basing on the complementarity of their substrate degradation patterns, particularly due to their M-/G-preference and substrate-size dependence. In addition, a novel method for sequencing alginate oligosaccharides was developed for the first time by combining the ${ }^{1} \mathrm{H}$ NMR spectroscopy and the enzymatic digestion with the exo-lyase AlyPB2, and this method is much simpler than traditional methods based on one- and two-dimensional NMR spectroscopy. Using this strategy, the sequences of the final tetrasaccharide and pentasaccharide product fractions produced by AlyPB1 were easily determined: the tetrasaccharide fractions contained two structures, $\triangle G M M$ and $\triangle M M M$, at a molar ratio of 1:3.2, and the pentasaccharide fractions contained four structures, $\triangle M M M M, \triangle M G M M, \triangle G M M M$, and $\triangle G G M M$, at a molar ratio of 1:1.5:3.5:5.25.

Conclusions: The identification of these two novel alginate lyases provides not only excellent candidate tool-type enzymes for oligosaccharide preparation but also a good model for studying the synergistic digestion and saccharification of alginate in biofuel production. The novel method for oligosaccharide sequencing described in this study will offer a very useful approach for structural and functional studies on alginate.

Keywords: Alginate, Alginate lyase, Synergistic effect, Biofuel, Oligosaccharide sequencing

\footnotetext{
*Correspondence: fuchuanli@sdu.edu.cn

National Glycoengineering Research Center and Shandong Key

Laboratory of Carbohydrate Chemistry and Glycobiology, Shandong

University, 72 Binhai Rd, Qingdao 266200, People's Republic of China
} 


\section{Background}

Currently, macroalgae and microalgae are attracting increasing attention and are emerging as alternative and environmentally friendly feedstocks for the production of biofuels, such as bio-ethanol, bio-hydrogen and biooil, due to rising energy demands [1-4]. Moreover, algae are widely used in the food, cosmetic, and pharmaceutical industries because they can produce some high-value products that are beneficial to human health, such as bio-pigments, vitamins and minerals $[5,6]$. As an alternative biomass, macroalgae in particular possess several crucial features: they require no fresh water, arable land, or fertilizer; they can control atmospheric $\mathrm{CO}_{2}$; and their cultivation avoids the conflict between food and fuels [7, 8]. The main polysaccharide component of brown macroalgae is alginate, which composes approximately $40 \%$ of the dry weight of algal biomass [9]. Alginate is a linear polysaccharide composed of repeating units of $\beta$-Dmannuronate $(\mathrm{M})$ and its $\mathrm{C} 5$ epimer, $\alpha$-L-guluronate $(\mathrm{G})$, which are arranged into homopolyuronic blocks (polyM or polyG) and heteropolyuronic blocks (polyMG or polyGM) [10-12]. Alginate is the major component of the brown algal cell wall and has recently attracted interest due to its potential for biofuel, food and pharmaceutical applications $[13,14]$.

Alginate lyase is a polysaccharide-degrading enzyme that specifically degrades alginate via a $\beta$-elimination reaction, forming a 4,5-unsaturated double bond at the non-reducing ends of products; the unsaturated uronic acid residues are designated as the $\Delta$ units [15-17]. Alginate lyases are widespread, and based on their primary structures, they have been classified into seven polysaccharide lyase (PL) families in the Carbohydrate-Active Enzymes (CAZy) database: PL5, PL6, PL7, PL14, PL15, PL17 and PL18 [18-22]. According to their substrate specificity, alginate lyases can be divided into three classes: polyM-specific lyases, polyG-specific lyases and bifunctional lyases. Moreover, according to their substrate degradation pattern, alginate lyases can be distinguished as endolytic and exolytic enzymes. Most characterized alginate lyases belong to the endolytic type and possess relatively high enzyme activity [23]. Endolytic alginate lyases randomly cleave glycoside bonds within alginate chains and generate a series of unsaturated oligosaccharides ( $\geq$ UDP2) as final products, which cannot be directly converted into biofuel [24]. By contrast, exolytic alginate lyases act on the non-reducing/ reducing ends of alginate polysaccharides or oligosaccharides to release the unsaturated monomer $\Delta$ units, which are needed for the saccharification of alginate in the process of biofuel production [25-29].

Compared to endolytic lyases, only a few exolytic alginate lyases have been identified, and all of them have lower activity and poor stability [29]. Endolytic and exolytic alginate lyases often co-exist in the same genome and are thus thought to work synergistically to cause the fast and complete digestion and utilization of alginate by bacteria. However, the synergistic mechanisms of endolytic and exolytic alginate lyases from the same bacterium strain remain to be investigated in detail, although a few studies have attempted to exploit the synergistic effect of endolytic and exolytic alginate lyases to maximize the alginate saccharification rate by optimizing the conditions of the enzymatic reaction [30,31]. The biochemical characteristics and crystal structures of an endolytic alginate lyase, AlyA1, and an exolytic alginate lyase, AlyA5, from the marine flavobacterium Zobellia galactanivorans were studied in detail, but their synergistic effect was not investigated [32]. Although the synergistic effect of two exolytic alginate lyases, Oalc6 and Oalc17, was clearly elucidated based on the complementarity of their substrate specificity, specific activity and stability, their synergistic mechanism with endolytic lyases received little attention [24]. Thus, the synergistic mechanism of endolytic and exolytic alginate lyases still remains to be illustrated.

In this study, two novel alginate lyases, AlyPB1 and AlyPB2, were identified from the draft genome of a marine bacterium, Photobacterium sp. FC615 [33]. AlyPB1 and AlyPB2 were characterized as endolytic and exolytic alginate lyases, respectively, and showed a strong synergistic effect on the complete digestion of alginate. Most importantly, we found that the activity of the exolytic lyase AlyPB2 was substrate size dependent, which could reveal the synergistic mechanism of these two enzymes. In addition, using the exolytic lyase AlyPB2 and ${ }^{1} \mathrm{H}$ NMR spectroscopy, a novel and simple method for sequencing alginate oligosaccharides was developed for the first time and successfully used to perform structural analysis of the main final products generated by AlyPB1.

\section{Methods \\ Materials and strains}

The strains and plasmids used in this study are listed in Table 1. PrimeSTAR ${ }^{\mathrm{TM}}$ HS DNA polymerases, restriction endonuclease, and other genetic engineering enzymes were purchased from Takara Inc. (Dalian, China). Cyanoborohydride $\left(\mathrm{NaBH}_{3} \mathrm{CN}\right), 2$-aminobenzamide (2-AB), sodium alginate (alginic acid sodium salt from brown algae, medium viscosity), hyaluronan, chondroitin sulfate, heparin and heparan sulfate were purchased from Sigma-Aldrich. PolyM $(M>90 \%)$ and polyG $(G>90 \%)$ were prepared from sodium alginate according to Haug et al. [11, 12]. Saturated alginate pentasaccharide and alginate polysaccharides $(10-25 \mathrm{kDa})$ were obtained by acid hydrolysis of alginate. Unsaturated alginate 
Table 1 Bacterial strains, plasmids, and primers used for sequencing in the present study

\begin{tabular}{|c|c|c|}
\hline Strains and plasmids & Description & Source \\
\hline \multicolumn{3}{|l|}{ Strains } \\
\hline Photobacterium sp. FC615 & A GAG-degrading marine bacterium & This study \\
\hline E. coli BL21(DE3) & $\mathrm{F}-$, ompT, hsdSB (rB-, mB-), dcm, gal, $\lambda(\mathrm{DE} 3)$, pLysS, Cmr & Novagen \\
\hline \multicolumn{3}{|l|}{ Plasmids } \\
\hline pET-22b & Expression vector; $A p^{r}$ & Novagen \\
\hline pET22b-alyPB1 & \multirow{2}{*}{$\begin{array}{l}\text { pET-22b carrying an amplified Ndel-Xhol fragment encoding the recombinant protein of } \\
\text { AlyPB1 or AlyPB2 fused with } \mathrm{A} \mathrm{His}_{6} \text { tag at the } \mathrm{C} \text { terminus }\end{array}$} & \multirow[t]{2}{*}{ This study } \\
\hline pET22b-alyPB2 & & \\
\hline \multicolumn{3}{|l|}{ Sequencing primers } \\
\hline AlyPB1-F & $5^{\prime}$-CATATGTCGACCCAAGATACACCAGTACCGG-3' & \\
\hline AlyPB1-R & $5^{\prime}$-CTCGAGGCTCTTCGGTGCAACCTGCAAACG-3' & \\
\hline AlyPB2-F & 5'-CATATGAAGCTGGAGAATGATACTTCAGCA-3' & \\
\hline AlyPB2-R & 5'-CTCGAGCAGCTCGATAGTCACTAACTCGCC-3' & \\
\hline
\end{tabular}

Restriction enzyme sites are underlined

$A p^{r}$ ampicillin-resistant

oligosaccharides (UDP2-UDP10) were prepared by the digestion of alginate using alginate lyase AlyPB1. And all other chemicals and reagents were of the highest quality available.

Marine bacterium Photobacterium sp. FC615 [33] was collected from Jiaozhou Bay, near Qingdao city in Shandong province, China. E. coli BL21 (DE3) was used for gene expression and it was cultured at $37{ }^{\circ} \mathrm{C}$ in LuriaBertani (LB) broth or on LB broth agar (LB broth supplemented with $1.5 \%$ agar) with ampicillin $(100 \mu \mathrm{g} / \mathrm{ml})$.

\section{Sequence analysis of AlyPB1 and AlyPB2}

$\mathrm{GC}$ contents (\%) of the open reading frames (ORFs) were determined, and the nucleotide sequences of ORFs were translated into corresponding amino acid sequences using Bio-Edit version 7.2.5 [34]. An online similarity search for the protein sequence was performed by the online BLAST algorithm through National Center for Biotechnology Information program. The secretion signal peptides and their types were predicted using the SignalP 4.1 server. Multiple sequence alignments and phylogenetic analyses were performed by MEGA version $5.05[35,36]$. The theoretical molecular weights $(\mathrm{Mw})$ were calculated through the peptide mass tool on the ExPASy server of the Swiss Institute of Bioinformatics. Protein modules and domains were identified using the Simple Modular Architecture Research Tool (SMART).

\section{Construction of recombinant expression vectors}

The genome sequence of Photobacterium sp. FC615 was sequenced and annotated at Meiji Biotech Inc. (Shanghai, China), which contains two putative alginate lyase genes alyPB1 and alyPB2. The genomic DNA was extracted and purified with the commercial genomic DNA purification kit (TianGen Biotech Co. Ltd., Beijing, China). To express AlyPB1 and AlyPB2 in E. coli BL21 (DE3), the full-length genes of alyPB1 and alyPB2 without the signal peptide sequence were amplified using high fidelity Prime STAR $^{\mathrm{TM}}$ HS DNA polymerases (TaKaRa Inc., Dalian, China) and the primer pairs. The primer pairs with restriction enzyme sites were designed according to the inserting site sequences of the expression vector $\mathrm{pET}-22 \mathrm{~b}$ $(+)$ (Novagen). Then the gel-recovered PCR products were ligated to the expression vector through the restriction enzyme sites NdeI and XhoI, yielding the recombinant plasmids pET22b-alyPB1 and pET22b-alyPB2. The recombinant expression plasmids pET22b-alyPB1 and pET22b-alyPB2 were transformed into E. coli BL21 (DE3) cells. The integrities of the nucleotide sequences of recombinant expression plasmids were confirmed through DNA sequencing at Sangon Biotech (Shanghai, China).

\section{Heterologous expression and purification of AlyPB1 and AlyPB2}

Escherichia coli BL21 (DE3) cells harboring a recombinant plasmid pET22b-alyPB1 and pET22b-alyPB2 were cultured in $100 \mathrm{ml} \mathrm{LB}$ medium containing $100 \mu \mathrm{g} /$ $\mathrm{ml}$ ampicillin and shaken for approximately $2 \mathrm{~h}$ at $37^{\circ} \mathrm{C}$ at $200 \mathrm{rpm}$. When the $\mathrm{OD}_{600}$ of the cell density reached $0.6-0.8$, the cells were induced to start target protein expression by addition of the inducer isopropyl 1-thio- $\beta$ D-galactoside (IPTG) at a final concentration of $0.05 \mathrm{mM}$ with shaking at $16{ }^{\circ} \mathrm{C}$ for $24 \mathrm{~h}$ at $220 \mathrm{rpm}$. The cells were harvested by centrifugation $\left(8000 \times g\right.$ for $10 \mathrm{~min}$ at $\left.4{ }^{\circ} \mathrm{C}\right)$, washed twice using pre-cooled buffer A $(50 \mathrm{mM}$ Tris, $150 \mathrm{mM} \mathrm{NaCl}, \mathrm{pH} 8.0$ ), resuspended in buffer $\mathrm{A}$ and disrupted by sonication (72 repetitions, $4 \mathrm{~s}$ ) in an ice 
cold environment. The cell lysate was centrifuged again $\left(15,000 \times g\right.$ for $30 \mathrm{~min}$ at $\left.4{ }^{\circ} \mathrm{C}\right)$; then, the supernatant fluid of the cell lysate containing the (His) ${ }_{6}$-tagged target protein was loaded onto a column packed with nickelSepharose $^{\mathrm{TM}} 6$ Fast Flow (GE Healthcare) equilibrated with buffer A. To prevent the adsorption of impurities, the column was washed with washing buffer $(50 \mathrm{mM}$ Tris, $150 \mathrm{mM} \mathrm{NaCl}, 5 \mathrm{mM}$ imidazole, $\mathrm{pH}$ 8.0) before the supernatant was loaded. The target protein was eluted with elution buffer, which was buffer A supplemented with a linear gradient concentration of imidazole (50$250 \mathrm{mM})$. The purity and molecular weight of the elution fractions were analysed by $13.2 \%$ sodium dodecyl sulfate polyacrylamide gel electrophoresis (SDS-PAGE) according to the methods described by Sambrook et al. [37]. The concentration of the target protein was determined using a BCA (bicinchoninic acid) protein assay kit. Finally, imidazole in the elution fractions was removed by ultrafiltration.

\section{Assay of AlyPB1 and AlyPB2 activities toward various polysaccharide substrates}

To determine the substrate specificity of AlyPB1 and AlyPB2, various polysaccharides (e.g., hyaluronan, chondroitin sulfate, heparin, heparan sulfate, alginate, polyM and polyG) were individually dissolved in deionized water to prepare stock solutions $(3 \mathrm{mg} / \mathrm{ml})$. The enzymatic reaction system was mixed with $100 \mu \mathrm{l}$ of $150 \mathrm{mM}$ $\mathrm{NaH}_{2} \mathrm{PO}_{4}-\mathrm{Na}_{2} \mathrm{HPO}_{4}$ buffer ( $\mathrm{pH}$ 8.0), $100 \mu \mathrm{l}$ of polysaccharide substrates, $30 \mu \mathrm{l}$ of the appropriately diluted enzyme, and $70 \mu \mathrm{l}$ of deionized water and then incubated at $30{ }^{\circ} \mathrm{C}$ for $12 \mathrm{~h}$. The reactions were terminated by heating in boiling water for $10 \mathrm{~min}$, subsequently cooled to $4{ }^{\circ} \mathrm{C}$ and centrifuged at $15,000 \times g$ for $10 \mathrm{~min}$. The supernatants were collected for analysis. The reaction products were assayed by measuring the increase in absorbance at $235 \mathrm{~nm}$ and via gel filtration HPLC.

\section{Biochemical characterization of the recombinant proteins AlyPB1 and AlyPB2}

The optimal $\mathrm{pH}$ was determined using the following buffers with different $\mathrm{pH}$ values: $50 \mathrm{mM} \mathrm{NaAc-HAc}$ buffer (pH 5.0-6.0), $50 \mathrm{mM} \mathrm{NaH} \mathrm{PO}_{4}-\mathrm{Na}_{2} \mathrm{HPO}_{4}$ buffer $(\mathrm{pH}$ 6.0-8.0) and $50 \mathrm{mM}$ Tris-HCl buffer (pH 7.0-10.0). These experiments were performed in a total volume of $300 \mu \mathrm{l}$ at $30^{\circ} \mathrm{C}$ for $1 \mathrm{~h}$. The optimal temperature was measured in $50 \mathrm{mM} \mathrm{NaH} \mathrm{PO}_{4}-\mathrm{Na}_{2} \mathrm{HPO}_{4}$ buffer $(\mathrm{pH}$ 8.0) at various temperatures, ranging from 0 to $70{ }^{\circ} \mathrm{C}$. To determine the thermostability of the recombinant proteins, their residual enzyme activities were measured after they were incubated at various temperatures from 0 to $70{ }^{\circ} \mathrm{C}$ for $0-24 \mathrm{~h}$. The effects of metal ions and chelators were evaluated by measuring the enzyme activities in the presence of various metal ions and chelators, respectively, at concentrations of $1 \mathrm{mM}$ and $10 \mathrm{mM}$. All reactions were performed in triplicate. After each treatment, the enzyme activity was estimated by measuring the absorbance at $235 \mathrm{~nm}$.

\section{Enzyme activity assay}

The enzymatic reaction system was prepared by mixing $100 \mu \mathrm{l}$ of $150 \mathrm{mM} \mathrm{NaH} \mathrm{PO}_{4}-\mathrm{Na}_{2} \mathrm{HPO}_{4}$ buffer (pH 8.0); $100 \mu \mathrm{l}$ of $3 \mathrm{mg} / \mathrm{ml}$ sodium alginate, polyG or polyM; $30 \mu \mathrm{l}$ of the appropriately diluted enzyme; $30 \mu \mathrm{l}$ of $100 \mathrm{mM}$ $\beta$-mercaptoethanol; and $40 \mu \mathrm{l}$ of deionized water and then allowed to operate under the optimal reaction conditions for 1-10 $\mathrm{min}$. The reactions were terminated by heating in boiling water for $10 \mathrm{~min}$, were subsequently cooled to $4{ }^{\circ} \mathrm{C}$ and were centrifuged at $15,000 \times g$ for $10 \mathrm{~min}$. The supernatants were transferred for analysis as described above. One unit was defined as the amount of enzyme required to release $1 \mu \mathrm{mol}$ of the reducing sugars/min under the optimal reaction conditions.

\section{Polysaccharide-degrading properties and oligosaccharide-yielding properties of AlyPB1 and AlyPB2}

To determine the enzymatic depolymerization pattern of sodium alginate by AlyPB1 and AlyPB2, enzymatic reactions were initiated and maintained under the optimal reaction conditions for $0-72 \mathrm{~h}$ at appropriate time intervals. After incubation, the reaction mixtures were boiled for $10 \mathrm{~min}$, subsequently cooled to $4{ }^{\circ} \mathrm{C}$, and centrifuged at $15,000 \times g$ for $10 \mathrm{~min}$. The supernatants were collected for analysis. The molar ratio of each unsaturated oligosaccharide fraction in the products was analysed by gel filtration chromatography on a preequilibrated Superdex peptide 10/300 GL column (GE Healthcare) and monitored at $235 \mathrm{~nm}$ by a UV detector. The mobile phase was $0.2 \mathrm{M} \mathrm{NH}_{4} \mathrm{HCO}_{3}$, and its flow rate was $0.4 \mathrm{ml} / \mathrm{min}$. Online monitoring and data analysis (e.g., molar ration determination) were performed using the software LCsolution version 1.25.

To investigate the orientation of degradation of AlyPB2, saturated alginate pentasaccharide was fluorescently labeled at the reducing ends using excess 2-AB (SigmaAldrich, USA) [38]. 2-AB-labeled saturated alginate pentasaccharide (2-AB-DP5) was digested by AlyPB2 under the optimal conditions, and the degradation products $(10 \mathrm{pmol})$ were removed at appropriate time intervals for time-course experiments. The reaction mixtures were treated as described above and analysed by gel filtration chromatography on a preequilibrated Superdex peptide 10/300GL column (GE Healthcare) using a fluorescence detector with excitation and emission wavelengths of 330 and $420 \mathrm{~nm}$, respectively. 
To demonstrate the oligosaccharide-yielding properties of AlyPB1 and AlyPB2, $150 \mathrm{mg}$ of sodium alginate was exhaustively digested with excessive amounts of the enzymes under the corresponding optimal conditions for $72 \mathrm{~h}$. The unsaturated oligosaccharides in the final product were size-fractionized and collected by gel filtration chromatography at $235 \mathrm{~nm}$ as described above. The mass/charge ratio of each unsaturated oligosaccharide fraction in the final products was identified by MS on an ion trap TOF hybrid mass spectrometer (LCMS-IT-TOF, Shimadzu, Japan). Electrospray ionization MS analysis was performed in negative ion mode with the following parameters: source voltage, $3.6 \mathrm{kV}$; nebulizer nitrogen gas flow rate, $1.5 \mathrm{l} / \mathrm{min}$; heat block and curved desolvation line temperatures, $200{ }^{\circ} \mathrm{C}$; and detector voltage, $1.8 \mathrm{kV}$. The mass acquisition range was set at 200-600.

\section{Sequencing of unsaturated alginate oligosaccharides using ${ }^{1} \mathrm{H}$ NMR spectroscopy combined with digestion by the exolytic lyase AlyPB2}

To determine the structures of the main final products produced by AlyPB1, size-defined oligosaccharides (UDP2, UDP3, UDP4 and UDP5) were prepared from the final digest of alginate by AlyPB1 through gel filtration chromatography as described above. The monosaccharide residues located at the reducing ends and next to the $\Delta$ units at the non-reducing ends of unsaturated alginate oligosaccharides could be assigned according to their characteristic chemical shift by ${ }^{1} \mathrm{H}$ NMR spectroscopy, and thus, the monosaccharide sequences of UDP2 and UDP3 were directly determined by ${ }^{1} \mathrm{H}$ NMR spectroscopy as described previously [39-42]. However, the internal monosaccharide residues of larger unsaturated oligosaccharides were difficult to determine using only ${ }^{1} \mathrm{H}$ NMR spectroscopy. Thus, UDP4 or UDP5 was partially degraded by the exolytic alginate lyase AlyPB2 to prepare a series of intermediate oligosaccharide products. The intermediate products, i.e. UDP3 from UDP4 (UDP3-UDP4) or UDP3 and UDP4 from UDP5 (UDP3-UDP5, UDP4-UDP5), were size-fractionized and collected by gel filtration chromatography at $235 \mathrm{~nm}$. Next, the structures of these intermediate unsaturated oligosaccharides from UDP4 and UDP5 were determined by ${ }^{1} \mathrm{H}$ NMR spectroscopy (Fig. 7). According to the results of the ${ }^{1} \mathrm{H}$ NMR spectroscopy analysis of the intermediate products, the internal structure of UDP4 or UDP5 was able to be determined. ${ }^{1} \mathrm{H}$-NMR spectroscopy was performed on a JNM-ECP600 (JEOL, Japan) instrument set at $600 \mathrm{MHz}$. Each sample $(2 \mathrm{mg})$ was dissolved in $0.5 \mathrm{ml}$ of $\mathrm{D}_{2} \mathrm{O}$ in a $5 \mathrm{~mm}$ NMR tube.

\section{Activity assay of AlyPB2 towards alginate substrates} with different molecular sizes

To determine the activity of AlyPB2 towards alginate substrates with different molecular sizes, unsaturated oligosaccharides (UDP2-UDP10) and saturated alginate polysaccharides $(10-25 \mathrm{kDa})$ were prepared from the degradation of alginate by the endolytic lyase AlyPB1 and acid hydrolysis, respectively. The enzymatic reaction system was prepared by mixing $30 \mu \mathrm{l}$ of $150 \mathrm{mM} \mathrm{NaH}_{2} \mathrm{PO}_{4}-$ $\mathrm{Na}_{2} \mathrm{HPO}_{4}$ buffer ( $\mathrm{pH} 8.0$ ), $30 \mu \mathrm{l}$ of polysaccharide or oligosaccharide substrates $(3 \mathrm{mg} / \mathrm{ml})$ with different molecular sizes, $9 \mu \mathrm{l}$ of the appropriately diluted enzyme, $9 \mu \mathrm{l}$ of $100 \mathrm{mM} \beta$-mercaptoethanol and $12 \mu \mathrm{l}$ of deionized water and allowed to proceed under the optimal reaction conditions for 1-10 $\mathrm{min}$. The reaction products were treated as described above and assayed by measuring the increase in absorbance at $235 \mathrm{~nm}$.

\section{Analysis of the synergistic effect of AlyPB1 and AlyPB2}

To investigate the synergistic effect of AlyPB1 and AlyPB2, the enzymatic reaction system was prepared by mixing $10 \mu \mathrm{l}$ of $150 \mathrm{mM} \mathrm{NaH} \mathrm{PO}_{4}-\mathrm{Na}_{2} \mathrm{HPO}_{4}$ buffer (pH 8.0), $10 \mu \mathrm{l}$ of sodium alginate $(3 \mathrm{mg} / \mathrm{ml}), 1.14 \mu \mathrm{l}(50 \mathrm{mU})$ of exolytic AlyPB2, $2.7 \mu \mathrm{l}(50 \mathrm{mU})$ of endolytic AlyPB1 and $6.16 \mu \mathrm{l}$ of deionized water and allowed to proceed at $20^{\circ} \mathrm{C}$ for $10 \mathrm{~min}$. Two control groups containing $100 \mathrm{mU}$ of the endolytic alginate lyase AlyPB1 or $100 \mathrm{mU}$ of the exolytic alginate lyase AlyPB2 were also set up. The resultant products were treated and analysed by gel filtration as described above at a wavelength of $235 \mathrm{~nm}$.

\section{Results}

\section{Sequence analysis of AlyPB1 and AlyPB2}

The genome of the marine bacterium Photobacterium sp. FC615 contains two putative alginate lyase genes: alyPB1 (ORF 02243, GenBank ${ }^{\mathrm{TM}}$ Accession No. MN116685) and alyPB2 (ORF 02710, GenBank ${ }^{\text {TM }}$ Accession No. MN116686). An additional ORF, 02280, has been annotated as an alginate lyase gene, but the protein encoded by this putative gene has no enzyme activity on any alginate associated substrates.

The ORF of gene alyPB1 is $1638 \mathrm{bp}$ in length, has a GC content of $51 \%$ and encodes a protein, AlyPB1, composed of 545 amino acids including a signal peptide of 21 amino acids. The recombinant protein AlyPB1 composed of 524 amino acids has a calculated molecular mass of $57.6 \mathrm{kDa}$ and an isoelectric point (pI) of 4.88. According to multiple sequence alignments and phylogenetic analysis with characterized sequences in the GenBank database, AlyPB1 belongs to PL6 family (Fig. 1b). AlyPB1 has a chondroitinase $\mathrm{B}$ module that is composed of 397 amino acids from $\mathrm{Thr}^{74}$ to $\mathrm{Asp}^{470}$, but AlyPB1 has no enzyme 


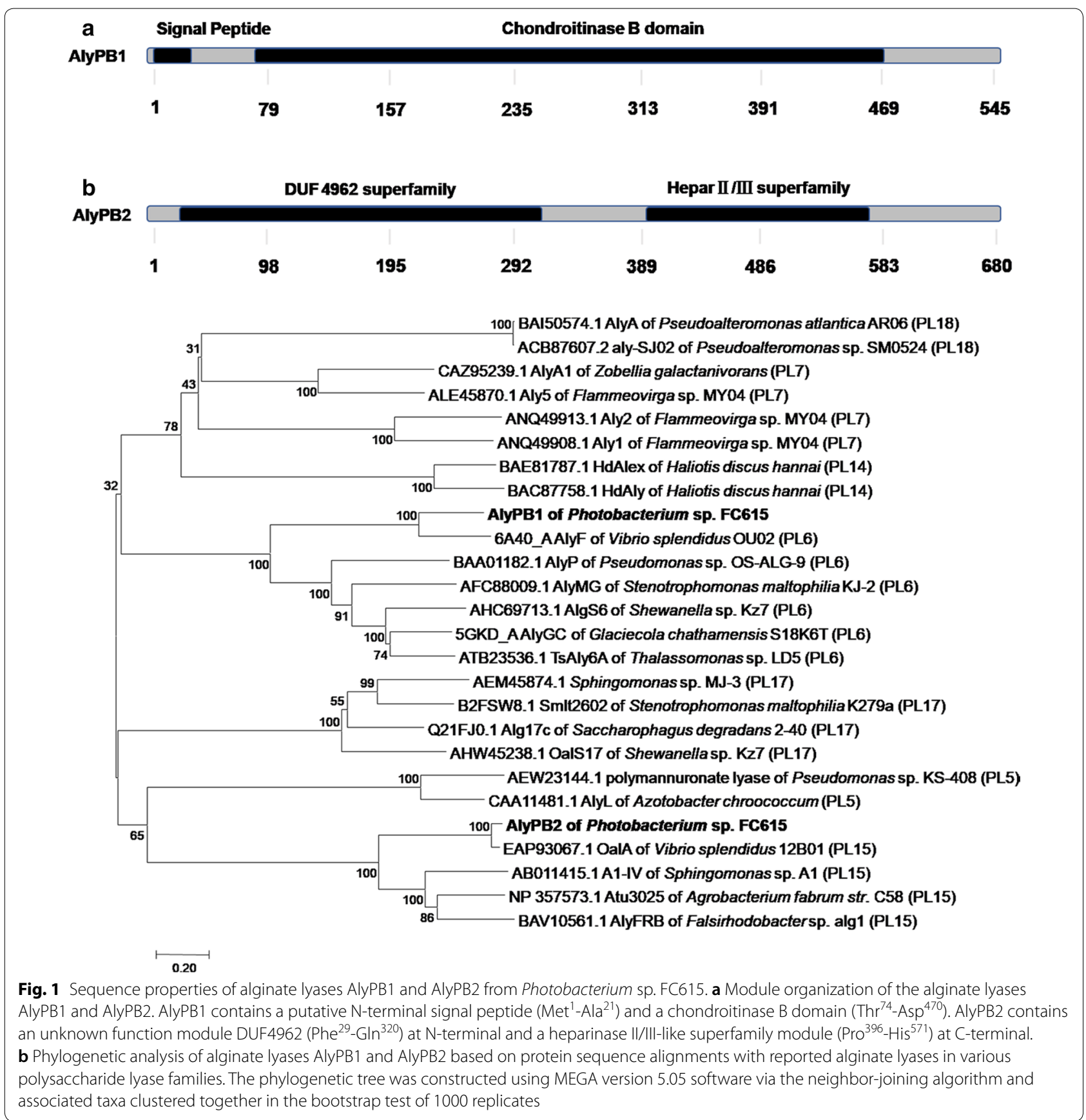

activity on chondroitin sulfate B (dermatan sulfate), as shown in Fig. 1a. A BLASTp search indicated that among the identified alginate lyases in PL6 family, AlyPB1 shares the greatest identity (60.23\%, query cover 97\%) with AlyF (6A40_A) from Vibrio OU02 [43]; 31.6\% identity (query cover 68\%) with AlgS6 (AHC69713.1) from Shewanella sp. Kz7 [44]; 28.1\% identity (query cover 80\%) with a poly MG-specific alginate lyase, AlyMG (AFC88009.1), from Stenotrophomonas maltophilia [21]; 29.7\% identity (query cover 63\%) with AlyGC (5GKD_A) from the marine bacterium Glaciecola chathamensis $\mathrm{S} 18 \mathrm{~K}^{\mathrm{T}}$ [18]; $30.6 \%$ identity (query cover $57 \%$ ) with a polyM-specific alginate lyase, AlyP (BAA01182.1), from Pseudomonas sp. OS-ALG-9 [10]; and 28.8\% identity (query cover 63\%) with TsAly6A (ATB23536.1) from Thalassomonas sp. LD5 [45].

The ORF of gene alyPB2 is $2043 \mathrm{bp}$ in length, has a GC content of $49 \%$, and encodes a protein, AlyPB2, 
composed of 680 amino acids without signal peptide. The recombinant protein AlyPB2 has a calculated molecular mass of $77.7 \mathrm{kDa}$ and an isoelectric point (pI) of 5.01. In the neighbour-joining phylogenetic tree, AlyPB2 was clustered with PL15 family together with the elucidated exolytic alginate lyases Atu3025 (NP_357573.1) from Agrobacterium tumefaciens strain C58 [27, 46], A1-IV (AB011415.1) from Sphingomonas sp. A1 [25, 26], OalA (EAP93067.1) from Vibrio splendidus 12B01 [28] and AlyFRB (BAV10561.1) from Falsirhodobacter sp. alg1 [47] (Fig. 1b). According to their primary structure, exolytic alginate lyases are generally separated into PL15 and PL17 family. To date, only five members of the PL15 family have been identified, including AlyPB2. SMART analysis demonstrated that the exolytic alginate lyases in PL15 family contain a DUF4962 superfamily module at their $\mathrm{N}$-terminus and a heparinase II/III superfamily module at their C-terminus. The function of the DUF4962 superfamily domain is unknown. The heparinase II/ III domain in AlyPB2 contains 176 amino acids, from $\mathrm{Pro}^{396}$ to $\mathrm{His}^{571}$, but as found in other alginate lyases, AlyPB2 did not show any heparinase activity (Fig. 1a). A BLASTp search showed that AlyPB2 shares the highest identity with OalA (93.4\%, query cover 100\%), as well as $42.1 \%$ sequence identity (query cover $89 \%$ ) with Atu3025 and 39.9\% (query cover 89\%) and 38.1\% (query cover 92\%) sequence identity with A1-IV and AlyFRB, respectively.

\section{Heterologous expression of AlyPB1 and AlyPB2 in E. coli}

Heterologous expression systems for the recombinant alginate lyases AlyPB1 and AlyPB2 were constructed in E. coli BL21 (DE3) cells as follows: the alyPB1 and alyPB2 were directly amplified from genomic DNA of Photobacterium sp. FC615; then, the PCR products were cloned into the pET-22b $(+)$ expression vector downstream of a T7 promoter. The pET-22b $(+)$ expression vector was designed to express recombinant protein labeled with $\mathrm{a} \mathrm{His}_{6}$ tag at the $\mathrm{C}$ terminus. SDS-PAGE showed that AlyPB1 (Fig. 2a) and AlyPB2 (Fig. 2b) purified as a single band at approximately $58 \mathrm{kDa}$ and $78 \mathrm{kDa}$, respectively, consistent with the calculated molecular masses. The purities of both of the two purified proteins were greater than $98 \%$. The concentration $(0.2 \mathrm{mg} / \mathrm{ml})$ of purified protein AlyPB1 was much lower than that $(4 \mathrm{mg} / \mathrm{ml})$ of the purified protein AlyPB2.

\section{Enzymatic characteristics of AlyPB1 and AlyPB2}

Seven structurally different polysaccharides, namely, hyaluronan, chondroitin sulfate, heparin, heparan sulfate, alginate, polyM and polyG, were used to

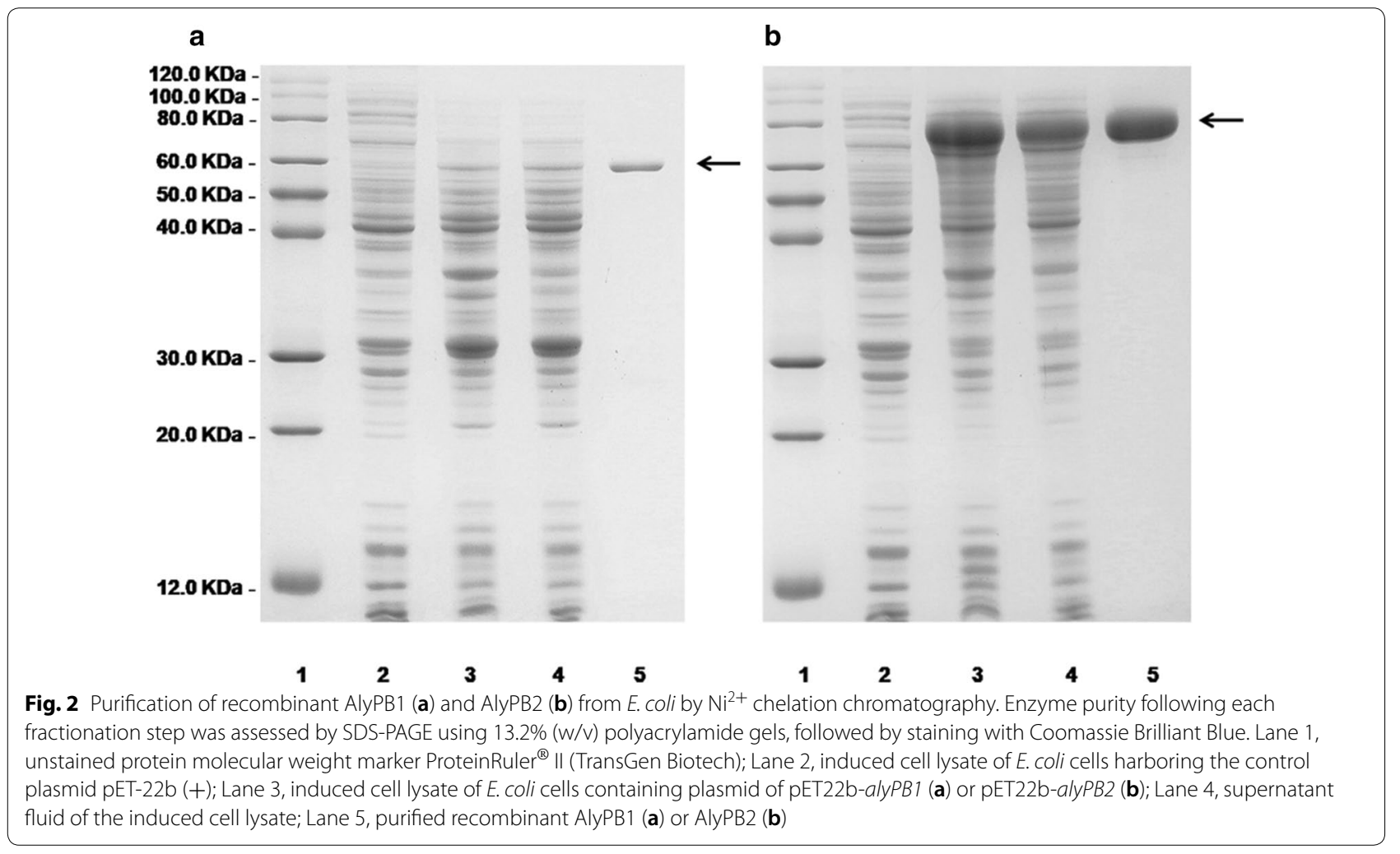


investigate the substrate preference of AlyPB1 and AlyPB2 by measuring the increase in absorbance at $235 \mathrm{~nm}$. AlyPB1 could efficiently digest only alginate and polyG, whereas AlyPB2 could efficiently digest alginate, polyM and polyG, suggesting that AlyPB1 and
AlyPB2 are alginate lyases that can degrade alginate and associated substrates by a $\beta$-elimination mechanism.

The enzymatic characteristics of AlyPB1 and AlyPB2 were further determined. AlyPB1 showed the highest enzyme activity at $30{ }^{\circ} \mathrm{C}$ (Fig. 3a) and retained more than
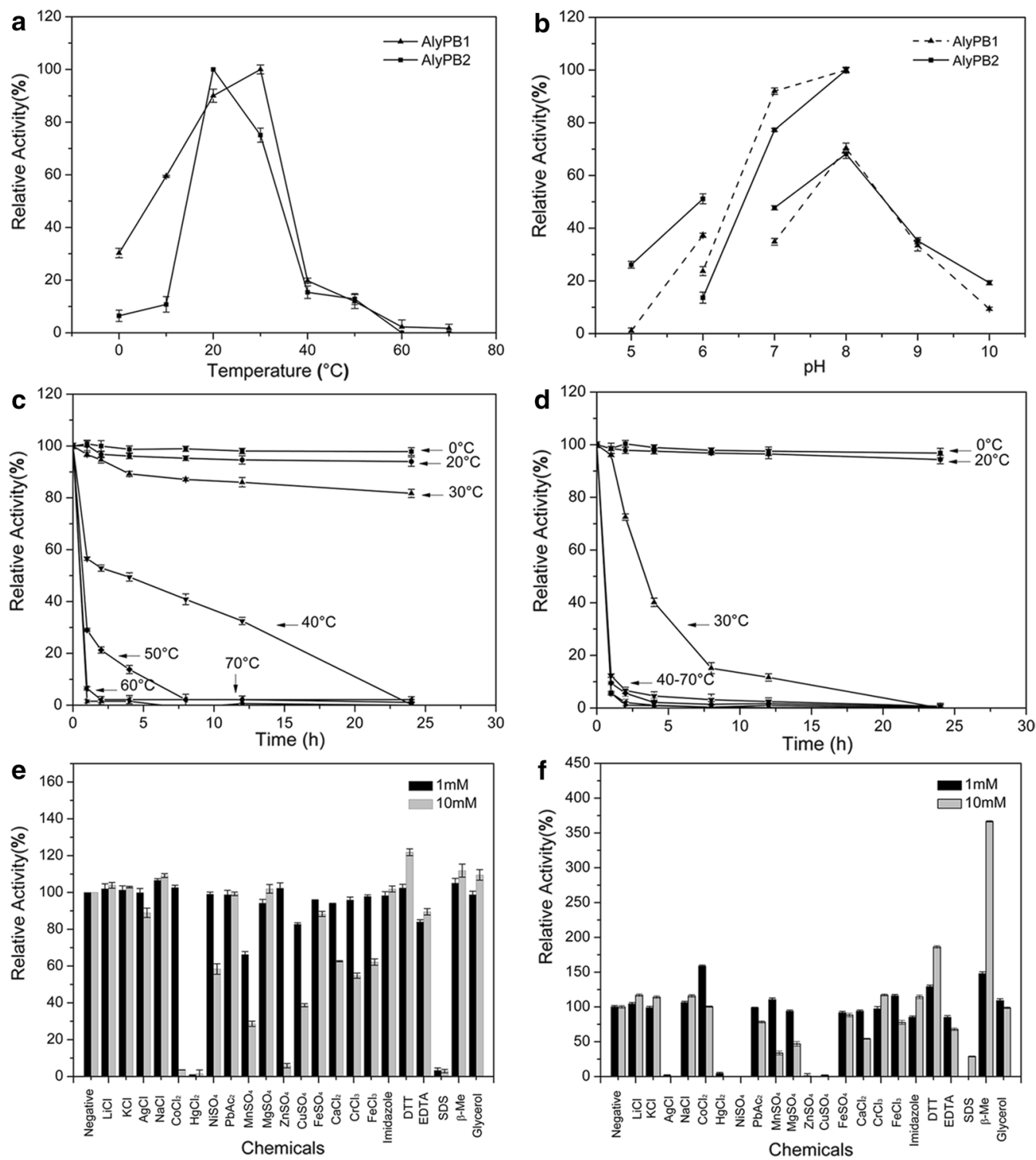

Fig. 3 Biochemical characteristics of the recombinant alginate lyases AlyPB1 and AlyPB2. a Effects of temperature. The enzyme activities of AlyPB1 and AlyPB2 were each measured using sodium alginate as substrate in the $50 \mathrm{mM} \mathrm{NaH}{ }_{2} \mathrm{PO}_{4}-\mathrm{Na}_{2} \mathrm{HPO}_{4}$ buffer ( $\mathrm{pH} 8.0$ ) at various temperatures $\left(0-70{ }^{\circ} \mathrm{C}\right)$ for $1 \mathrm{~h}$. Data are shown as the percentage of the activity of that obtained at $30^{\circ} \mathrm{C}$ for AlyPB1 and at $20{ }^{\circ} \mathrm{C}$ for AlyPB2 (100\%). $\mathbf{b}$ Effects of $\mathrm{pH}$ values. The enzyme activities of AlyPB1 and AlyPB2 against sodium alginate were individually measured in buffers with varying pH values from 5.0 to 10.0 for $1 \mathrm{~h}$ at $30{ }^{\circ} \mathrm{C}$ of AlyPB1 and at $20^{\circ} \mathrm{C}$ of AlyPB2. Data are shown as the percentage of the activity of that obtained in 50 mM NaH ${ }_{2} \mathrm{PO}_{4}-$ $\mathrm{Na}_{2} \mathrm{HPO}_{4}$ buffer ( $\mathrm{pH}$ 8.0) (100\%). c, d Thermostability of AlyPB1 and AlyPB2. The enzymes were preincubated for 0-24 h under temperatures ranging from 0 to $70{ }^{\circ} \mathrm{C}$, and the residual activities against sodium alginate were estimated at $30{ }^{\circ} \mathrm{C}$ of $\mathrm{AlyPB} 1$ and at $20^{\circ} \mathrm{C}$ of $\mathrm{AlyPB} 2$. Data are shown as the activity relative to that of untreated AlyPB1 and AlyPB2. e, f Effects of various compounds on the enzyme activity of AlyPB1 and AlyPB2. The enzyme activities of AlyPB1 and AlyPB2 against sodium alginate were individually measured in the $\mathrm{NaH}_{2} \mathrm{PO}_{4}-\mathrm{Na}_{2} \mathrm{HPO}_{4}$ buffer (pH 8.0) containing a 1 mM or $10 \mathrm{mM}$ concentration of various compounds for $1 \mathrm{~h}$ at $30^{\circ} \mathrm{C}$ of AlyPB1 and at $20^{\circ} \mathrm{C}$ of AlyPB2. Data are shown as the percentage of the activity of obtained in the buffer without tested compounds. Error bars represent mean values of triplicates \pm SD 
Fig. 4 Degradation patterns of alginate polysaccharide by AlyPB1 and AlyPB2. a Time-course treatment of sodium alginate $(1.0 \mathrm{mg} /$ $\mathrm{ml}$ ) using AlyPB1 at $30^{\circ} \mathrm{C}$. $\mathbf{b}$ Time-course treatment of sodium alginate $(1.0 \mathrm{mg} / \mathrm{ml})$ using AlyPB2 at $20^{\circ} \mathrm{C}$. The unsaturated oligosaccharide products were analysed through a pre-equilibrated Superdex peptide 10/300 GL column monitored using a UV detector at $235 \mathrm{~nm}$. Degrees of polymerization of oligosaccharides are indicated on the peaks: UDP1, UDP2, UDP3, UDP4, UDP5 and UDP6 represent unsaturated monosaccharide, disaccharide, trisaccharide, tetrasaccharide, pentasaccharide and hexasaccharide; DEH and TPC are both converted products of unsaturated monosaccharide. c Analysis for the degradation orientation of exo-lyase AlyPB2. Time-course treatment of 2-AB-labeled saturated alginate pentasaccharide (2-AB-DP5) $(10 \mathrm{pmol})$ with AlyPB2 at $20^{\circ} \mathrm{C}$. The resulting products were analysed by gel filtration as described above but using a fluorescent detector with an excitation wavelength of $330 \mathrm{~nm}$ and an emission wavelength of $420 \mathrm{~nm}$. 2-AB-UDP2, 2-AB-UDP3 and 2-AB-UDP4 represent 2-AB-labeled unsaturated alginate disaccharide, trisaccharide and tetrasaccharide. $E(-)$, control treated with inactivated enzyme

w80\% of its original activity after incubation at temperatures from 0 to $30{ }^{\circ} \mathrm{C}$ for $24 \mathrm{~h}$ (Fig. 3c). The optimal pH of AlyPB1, determined at $30{ }^{\circ} \mathrm{C}$ in $50 \mathrm{mM} \mathrm{NaH}_{2} \mathrm{PO}_{4}-$ $\mathrm{Na}_{2} \mathrm{HPO}_{4}$ buffer, was 8.0 (Fig. 3b). By contrast, AlyPB2 had a lower optimal temperature $\left(20^{\circ} \mathrm{C}\right)$ and thermostability than AlyPB1 (Fig. 3a, d), though the optimal buffer of AlyPB2 $\left(\mathrm{NaH}_{2} \mathrm{PO}_{4}-\mathrm{Na}_{2} \mathrm{HPO}_{4}\right.$ buffer, $\mathrm{pH}$ 8.0) was the same as that of AlyPB1 (Fig. 3b). Furthermore, the activities of both AlyPB1 and AlyPB2 were strongly inhibited by $\mathrm{Hg}^{2+}, \mathrm{Ni}^{2+}, \mathrm{Mn}^{2+}, \mathrm{Zn}^{2+}, \mathrm{Cu}^{2+}$, and SDS (Fig. 3e, f). In addition, AlyPB2 was strongly inhibited by $\mathrm{Ag}^{+}$and $\mathrm{Mg}^{2+}$, but AlyPB1 was not (Fig. 3f). Notably, the enzymatic activity of AlyPB2 was increased to $158 \%$, $186 \%$ and $366 \%$ by stimulation with $\mathrm{Co}^{2+}$, DTT and $\beta$-mercaptoethanol, respectively (Fig. 3f). By contrast, the activity of AlyPB1 was not significantly stimulated by these chemicals and was strongly inhibited by $10 \mathrm{mM}$ $\mathrm{Co}^{2+}$ (Fig. 3e).

Under the optimal conditions of $30{ }^{\circ} \mathrm{C}$ in $50 \mathrm{mM}$ $\mathrm{NaH}_{2} \mathrm{PO}_{4}-\mathrm{Na}_{2} \mathrm{HPO}_{4}$ (pH 8.0), AlyPB1 showed much higher activity towards polyG $(1295 \mathrm{U} / \mathrm{mg})$ than alginate $(185 \mathrm{U} / \mathrm{mg})$, whereas AlyPB1 showed extremely low activity towards polyM $(<1 \mathrm{U} / \mathrm{mg})$. By contrast, the specific activities of AlyPB2 towards sodium alginate, polyM and polyG were $10.9,14.6$, and $8.5 \mathrm{U} / \mathrm{mg}$ protein, respectively, under the optimal conditions $\left(20^{\circ} \mathrm{C}\right.$ in $50 \mathrm{mM} \mathrm{NaH}{ }_{2} \mathrm{PO}_{4}-\mathrm{Na}_{2} \mathrm{HPO}_{4}, \mathrm{pH}$ 8.0). Interestingly, $\mathrm{AlyPB} 1$ and AlyPB2 have distinct preferences for polyG and polyM.

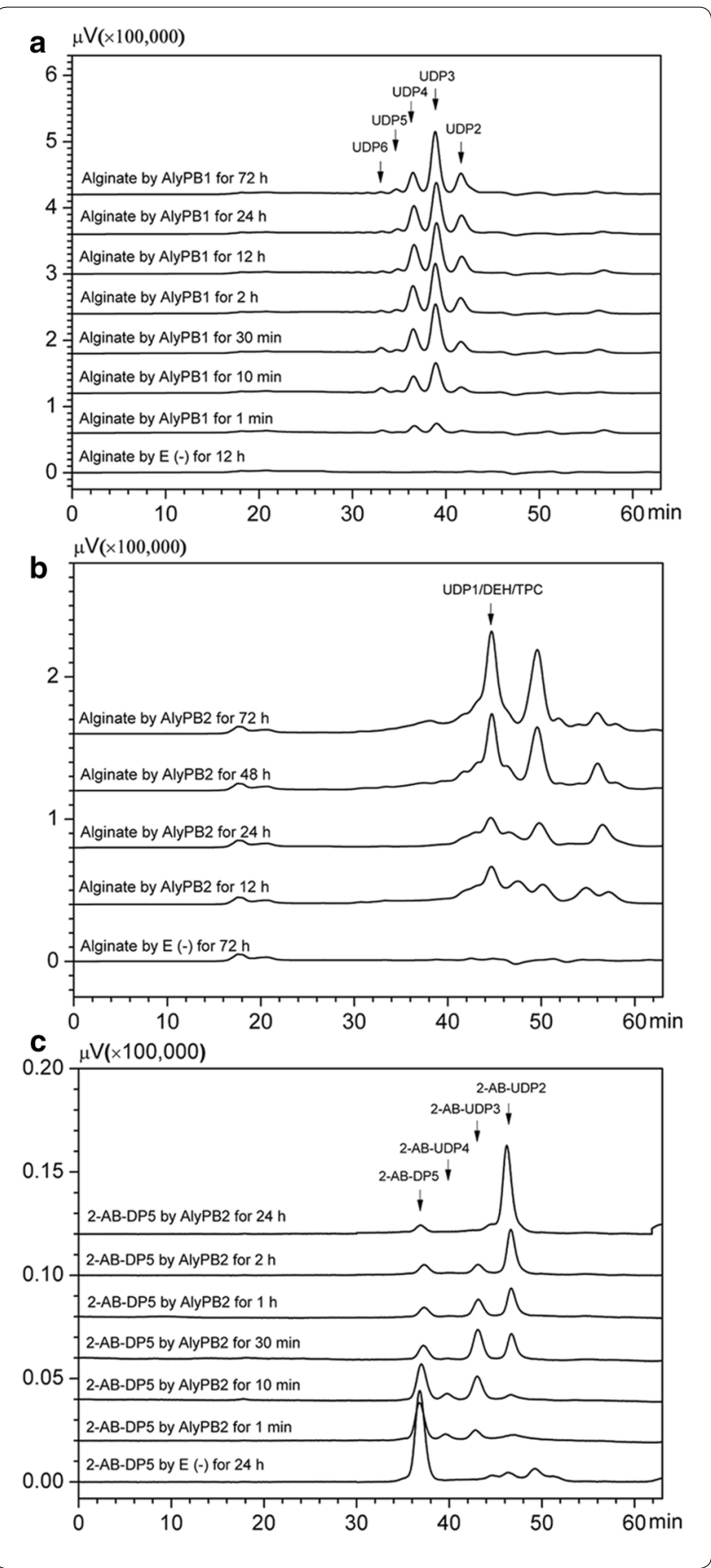

Polysaccharide degradation patterns and oligosaccharide-yielding properties of AlyPB1 and AlyPB2

Based on their substrate degradation patterns, alginate lyases are mainly classified into three types: endolytic lyases, exolytic lyases and combinations of both [1]. To investigate the substrate degradation patterns of AlyPB1 and AlyPB2, alginate polysaccharide was digested for $0-72 \mathrm{~h}$, and the resultant products were removed at 
appropriate time intervals and analysed by gel filtration. Unsaturated oligosaccharides with a high degree of polymerization (DP) were the main products in the initial stage of the reaction and were then gradually converted into smaller oligomers (Fig. 4a), indicating that AlyPB1 is an endo-type alginate lyase. Unlike AlyPB1, AlyPB2 did not digest alginate into oligosaccharides with $\mathrm{DP} \geq 2$ but rather produced unsaturated monosaccharides at all time points (Fig. 4b), suggesting that AlyPB2 is an exo-type alginate lyase that has the ability to remove monosaccharides from the end of alginate chains.

To exactly determine the substrate degradation orientation of the exo-lyase AlyPB2, saturated alginate pentasaccharide (DP5) was labeled with $2-\mathrm{AB}$ at the reducing end and further digested with AlyPB2 in a time-course experiment. The results of the gel filtration assay showed that the digestion of 2-AB-DP5 by AlyPB2 yielded a series of 2-AB-labeled oligosaccharide products with high molecular masses at the beginning of the reaction, and then, the larger products $2-\mathrm{AB}-\mathrm{UDP} 4$ and 2-ABUDP3 were gradually converted into the final product, 2-AB-UDP2 (Fig. 4c). This substrate degradation pattern clearly demonstrates that AlyPB2 is an exolytic lyase that removes uronic acid from the non-reducing ends of alginate chains. Notably, the digestion of 2-AB-labeled alginate oligosaccharides by AlyPB2 finally produced 2-AB-labeled disaccharides rather than monosaccharides due to the steric hindrance effect of the fluorescent label inhibiting further cleavage of 2-AB-labeled disaccharides at the reducing ends of alginate chains.

To further confirm the final products of alginate digestion by AlyPB1 and AlyPB2, alginate polysaccharide was digested with an excess of each enzyme under the optimal conditions for $72 \mathrm{~h}$. The final products were size-fractionated and collected by gel filtration chromatography with detection at $235 \mathrm{~nm}$. Among the final products of alginate digestion by AlyPB1, five major fractions were separately collected for ESI-MS analysis, and five major molecular ion peaks at $351 \mathrm{~m} / z[\mathrm{M}-\mathrm{H}]^{-}$, $527 \mathrm{~m} / z[\mathrm{M}-\mathrm{H}]^{-}, 703 \mathrm{~m} / z[\mathrm{M}-\mathrm{H}]^{-}, 879 \mathrm{~m} / z[\mathrm{M}-\mathrm{H}]^{-}$ and $1055 \mathrm{~m} / z[\mathrm{M}-\mathrm{H}]^{-}$were individually detected in the corresponding fractions (Fig. 5a-e). These molecular ion peaks could be assigned to unsaturated disaccharide (UDP2), trisaccharide (UDP3), tetrasaccharide (UDP4), pentasaccharide (UDP5) and hexasaccharide (UDP6), respectively, based on the calculation of their molecular masses. The molar ratio of these fractions was calculated to be 23:52:18.6:4:2.4 according to peak area integration of the gel filtration chromatograph. For AlyPB2, the final products had two main molecular ion peaks at $175 \mathrm{~m} / z$ $[\mathrm{M}-\mathrm{H}]^{-}$and $193 \mathrm{~m} / \mathrm{z}[\mathrm{M}-\mathrm{H}]^{-}$(Fig. 5f). Previously reported studies have demonstrated that the unsaturated monosaccharides produced by exo-type alginate lyases can be first non-enzymatically converted into 4-deoxyL-erythro-5-hexoseulose uronic acid (DEH) and then automatically transformed into 2, 4, 5, 6-tetrahydroxytetrahydro-2 $H$-pyran-2-carboxylic acid (TPC) [15, 44]. Thus, the main peaks at $175 \mathrm{~m} / z[\mathrm{M}-\mathrm{H}]^{-}$and $193 \mathrm{~m} / \mathrm{z}$ $[\mathrm{M}-\mathrm{H}]^{-}$corresponded to unsaturated monosaccharide/ $\mathrm{DEH}$ and TPC, respectively.

\section{Sequencing of AlyPB1-produced unsaturated oligosaccharides by ${ }^{1} \mathrm{H}$ NMR spectroscopy combined with digestion by AlyPB2}

To further identify the structures of the oligosaccharides produced by AlyPB1, five size-defined oligosaccharide fractions, UDP2-UDP6, were isolated from the final products of alginate digestion by AlyPB1, as described above. Because the chemical shifts of the protons of the $\Delta$ unit at the non-reducing end of alginate oligosaccharide are strongly affected by the property of the nearest monosaccharide residues, and the structure of the residue next to the $\Delta$ unit can be directly identified based on the $\mathrm{H}-4$ signal of the $\Delta$ unit in the ${ }^{1} \mathrm{H}-\mathrm{NMR}$ spectrum of the unsaturated oligosaccharides [17, 39-42]. In the case of UDP2 (Fig. 6a), the specific signal at $5.71 \mathrm{ppm}$ of $\mathrm{H}-4$ of $\Delta \mathrm{G}$ was much stronger than that (5.61 ppm) of $\mathrm{H}-4$ of $\Delta \mathrm{M}$, indicating that $\Delta \mathrm{G}$ was the main disaccharide product and that the molar ratio of $\Delta \mathrm{G}$ to $\Delta \mathrm{M}$ was approximately 3.4:1.0 (Table 2). Furthermore, the residues at the reducing ends of alginate oligosaccharides can be determined according to the characteristic signals of their anomeric protons because the $\beta$-anomeric protons of the $G$ and $M$ residues at the reducing ends have a characteristic doublet at $4.71 \mathrm{ppm}$ with ${ }^{3} \mathrm{~J}_{\mathrm{HH}}=8.4 \mathrm{~Hz}$ and a single peak at $4.70-4.80 \mathrm{ppm}$, respectively $[32,48]$. Thus, sequences of UDP3 from the final products can also be directly determined using ${ }^{1} \mathrm{H}$ NMR spectroscopy. As shown in Fig. $6 \mathrm{a}$, only the characteristic doublet at $4.71 \mathrm{ppm}$ was detected in the UDP3 sample, indicating that the reducing ends contained only $\mathrm{G}$ residues. Moreover, the molar ratio of the non-reducing end $\Delta \mathrm{G}$ to $\Delta \mathrm{M}$ was calculated to be $6.7: 1$ by integrating the areas of the $H-4 . \Delta G$ (5.67 ppm) and $\mathrm{H}-4 . \Delta \mathrm{M}(5.56 \mathrm{ppm})$ signals, suggesting that the UDP3 products contain two unsaturated trisaccharides, $\triangle \mathrm{GG}$ and $\triangle \mathrm{MG}$, at a ratio of $6.7: 1$ (Table 2).

By contrast, the sequences of the larger unsaturated oligosaccharide fractions, such as UDP4, UDP5 and UDP6, were difficult to determine through only their ${ }^{1} \mathrm{H}-\mathrm{NMR}$ spectra; however, their reducing and non-reducing monosaccharide residues can be identified by the method used to identify UDP2 and UDP3. According to the ${ }^{1} \mathrm{H}-\mathrm{NMR}$ spectra shown in Fig. 6a, structures of UDP4, UDP5 and UDP6 can be preliminarily determined to be $\triangle G X M$ and $\triangle M X M$ at a molar ratio of 1:3.2; $\triangle G X X M$ and $\triangle$ MXXM (3.5:1); and $\triangle$ GXXXM and $\triangle \mathrm{MXXXM}$ 


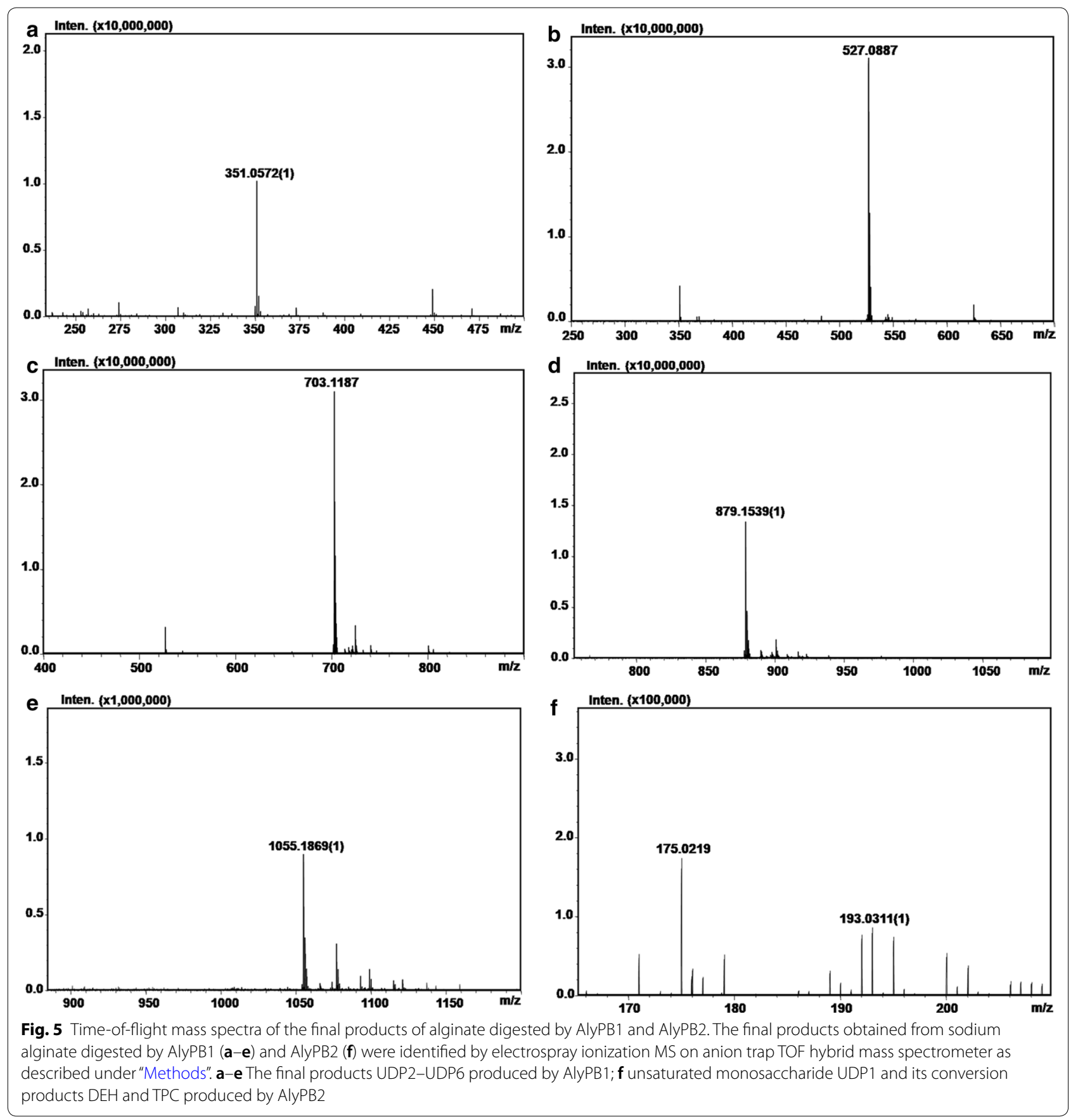

(1.6:1), in which $\mathrm{X}$ represents an unknown residue. Interestingly, the reducing-end residues of all the three larger products, i.e., the UDP4, UDP5 and UDP6 fractions, were $M$, which has a characteristic single peak at 4.70$4.80 \mathrm{ppm}$, completely different from the small products (UDP2 and UDP3), which have G as their reducing-end residues (Table 2 ).

To determine the unknown X residues inside the larger unsaturated alginate oligosaccharides, e.g., the UDP4 and
UDP5 fractions, a novel method was established by combining ${ }^{1} \mathrm{H}$ NMR spectroscopy with digestion by AlyPB2 (Fig. 7). Since AlyPB2, as a bifunctional exolytic alginate lyase, can sequentially remove monosaccharide residues one by one from the non-reducing end of the alginate chains, the unidentified $\mathrm{X}$ residue inside the chain can be exposed as $\Delta \mathrm{X}$ at the non-reducing end by appropriate partial digestion with AlyPB2, and the corresponding $\mathrm{X}$ residue can be easily identified by ${ }^{1} \mathrm{H}$ NMR spectroscopy, 


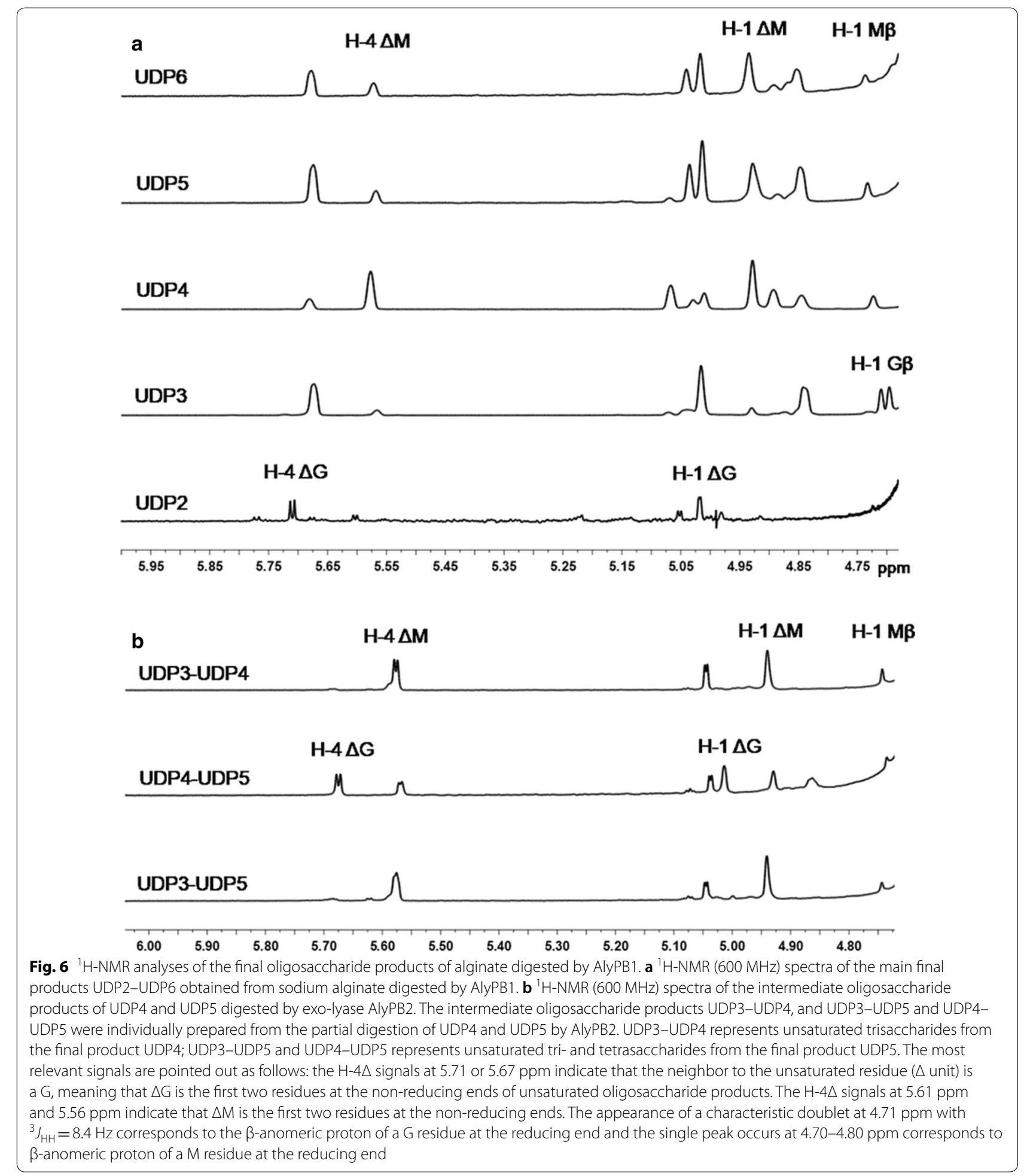

as mentioned above (Fig. 7). Thus, to identify the internal structures of UDP4 ( $\triangle \mathrm{GXM}$ and $\triangle \mathrm{MXM})$ produced by AlyPB1, the unsaturated trisaccharides UDP3-UDP4 ( $\triangle \mathrm{XM}$ and $\triangle \mathrm{XM}$ ) from the reducing ends of UDP4 were prepared by partial digestion with AlyPB2 and analysed by ${ }^{1} \mathrm{H}$ NMR spectroscopy. As shown in Fig. 6b, UDP3UDP4 still showed a single peak at $4.70-4.80 \mathrm{ppm}$, similar to its parent oligosaccharide UDP4, indicating that the reducing-end $M$ residues were not affected by treatment with AlyPB2. By contrast, a strong signal (5.56 ppm) 


\begin{tabular}{lc}
$\begin{array}{l}\text { Table } 2 \text { The structures and molar fractions of the final } \\
\text { unsaturated } \\
\text { oligosaccharide products } \\
\text { by AlyPB } 1\end{array}$ & $\begin{array}{l}\text { Menerated } \\
\text { polar } \\
\text { fraction } \\
\%\end{array}$ \\
\hline Final unsaturated oligosaccharide products of AlyPB1 & \\
& \\
\hline UDP2 & 77 \\
$\triangle G$ & 23 \\
$\triangle M$ & \\
UDP3 & 87 \\
$\triangle G G$ & 13 \\
$\triangle M G$ & \\
UDP4 & 76 \\
$\triangle M M M$ & 24 \\
$\triangle G M M$ & \\
UDP5 & 46.7 \\
$\triangle G G M M$ & 13.3 \\
$\triangle M G M M$ & 31.1 \\
$\triangle G M M M$ & 8.9 \\
$\triangle M M M M$ & \\
\hline
\end{tabular}

corresponding to $\mathrm{H}-4 \Delta \mathrm{M}$ but not $\mathrm{H}-4, \Delta \mathrm{G}$ was detected in the ${ }^{1} \mathrm{H}$ NMR spectrum of UDP3-UDP4 (Fig. 6b), suggesting that the $\mathrm{X}$ residues in both $\triangle \mathrm{XM}$ and $\triangle \mathrm{XM}$ are $\mathrm{M}$ residues. At this point, it can be concluded that there are two structures, $\triangle G M M$ and $\triangle M M M$, at a molar ratio of 1:3.2 in UDP4 produced by AlyPB1 (Table 2).

The structures of final UDP5 product fractions ( $\triangle \mathrm{GXXM}$ and $\triangle \mathrm{MXXM}$ ) produced by AlyPB1 were elucidated by preparing the unsaturated tetrasaccharides UDP4-UDP5 ( $\triangle X X M)$ and trisaccharides UDP3-UDP5 $(\triangle \mathrm{XM})$ at the reducing ends of UDP5 followed by ${ }^{1} \mathrm{H}$ NMR analysis, as performed for UDP4 (Figs. 6b, 7). Four structures were identified in the UDP5 fraction, $\triangle M M M M, \triangle M G M M, \triangle G M M M$ and $\triangle G G M M$, which had a molar ratio of $\sim$ :1.5:3.5:5.25 (Table 2). However, the structures of UDP6 could not be completely determined due to its relatively low proportion in the final products of alginate by AlyPB1 (Fig. 4a).

\section{Synergistic effect of AlyPB1 and AlyPB2}

Compared with AlyPB1, AlyPB2 has very low activity when both enzymes act on alginate polysaccharides. Since AlyPB2 is an exolytic lyase, it may prefer to digest small molecular size-defined substrates, such as intermediate oligosaccharide products, generated from the digestion of alginate by AlyPB1. To investigate this possibility, a series of alginate substrates with different molecular sizes was prepared by degradation of alginate with AlyPB1 or an acid. An enzymatic activity assay showed that the activity of AlyPB2 was strongly affected by the size of the substrates (Fig. 8a). Unsaturated tetrasaccharide UDP4 is the optimally sized substrate. Furthermore, the activity of AlyPB2 gradually decreases as the substrate size increases, and its activity towards UDP4 is approximately 6.5 times higher than that towards alginate polysaccharide (Fig. 8a). Notably, the activities of AlyPB2 towards UDP2 and UDP3 were not as high as that towards UDP4 (Fig. 8a), possibly because the former two were too small to bind to the enzyme with high affinity. Nevertheless, UDP2, as the smallest substrate, can be effectively degraded into the unsaturated monosaccharides, indicating that AlyPB1 and AlyPB2 can act together to completely digest alginate into monosaccharide units to facilitate the saccharification of alginate.

To further investigate the cooperative action of AlyPB1 and AlyPB2, alginate polysaccharide was treated with a mixture of these two enzymes $(100 \mathrm{mU})$ with an activity ratio of $1: 1$ at $20{ }^{\circ} \mathrm{C}$ for $10 \mathrm{~min}$. Gel filtration analysis showed that under the given reaction conditions, a small amount of UDP1 was produced when using AlyPB2 only, while the yield of UDP1 was dramatically increased approximately sevenfold when AlyPB1 and AlyPB2 acted on alginate together (Fig. 8b). These results suggest that the digestion of alginate by AlyPB1 strongly promotes the activity of AlyPB2 to release UDP1 from substrates, which is consistent with the finding that AlyPB2 prefers to digest alginate oligosaccharides rather than polysaccharides.

\section{Discussion}

Alginate, as a cost-competitive renewable source for biofuel production, has considerable research prospects [49, 50]. In the saccharification process of alginate, the synergistic effect of various alginate lyases with different substrate specificities and degradation modes plays a vital role [28]. Compared with individual enzyme biocatalysis, multiple enzyme biosystems enable improve utilization of alginate and decrease production costs on the basis of their complementary advantages.

In this study, the endo-lyase AlyPB1 and exo-lyase AlyPB2 were identified from a marine bacterium, Photobacterium sp. FC615. AlyPB1 was classified into the PL6 family and had the highest similarity (60.23\%) with AlyF, an elucidated alginate lyase in PL6 family [43]. AlyPB2 belongs to the PL15 family and has $<43 \%$ sequence identity with most of the previously elucidated exolytic alginate lyases in PL15 family, except for OalA from Vibrio splendidus 12B01 [28], which had the highest sequence identity of 93.4\% with AlyPB2. AlyPB1 and AlyPB2 are alginate lyases with preferences to polyG and polyM, respectively. AlyPB2 also exhibited obvious activity towards polyG, indicating that AlyPB2 is a bifunctional lyase. Similar to most of the identified enzymes in PL6 

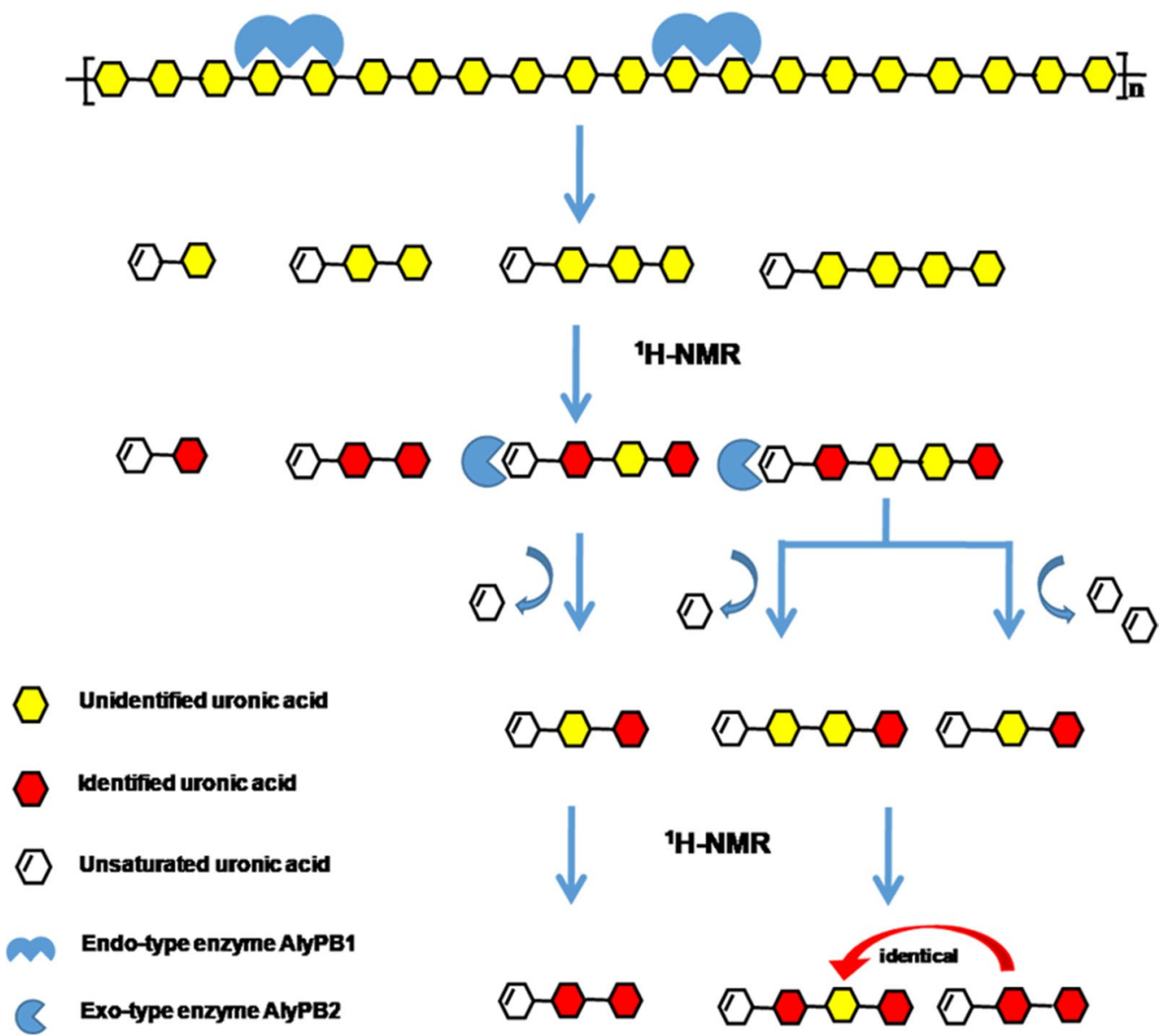

Fig. 7 Schematic diagram of the novel method for sequencing alginate oligosaccharides by combining ${ }^{1} H$ NMR spectroscopy and digestion with the exo-lyase AlyPB2

family, AlyPB1 has a polyG preference, but it shows much higher enzymatic activity than those of the other identified PL6 family enzymes, even the recently identified AlyF [43]. To date, only five alginate lyases, including AlyPB2, have been classified in the PL15 family, and all of them are exo-type lyases. Notably, the identified exo-type alginate lyases predominantly have a polyM preference, except AlgS6 in PL6 family and AlyA5 in PL7 family [32, 44].

AlyPB1 contains a type I signal peptide composed of 21 amino acids at its N-terminus, while AlyPB2 has no signal peptide, indicating their different subcellular localization in the native bacterium. Therefore, AlyPB1 is a typical secreted enzyme, whereas AlyPB2 is an intercellular enzyme, consistent with their basic enzymatic properties and functions in the alginate degradation. Although the optimal conditions for both enzymes are similar, AlyPB2 is much more sensitive to changes in the reaction conditions, which may be due to its relatively stable intercellular environment. AlyPB2 can be significantly enhanced by reducing agents, indicating that AlyPB2 may active in reducing intracellular environment. By contrast, AlyPB1, as an extracellular enzyme, can adapt to a flexible and dynamic environment. As a result, secreted AlyPB1 degrades alginate polysaccharides outside cells to produce oligosaccharides that can be easily transported into cells for final digestion by AlyPB2.

Exolytic lyases are not only key enzymes for the final digestion and saccharification of alginate but also important tools for the structural analysis of alginate chains. Thus, it is very important to investigate their substrate degradation patterns, such as their substrate preference and degradation direction. In previous studies, researchers mainly focused on substrate preferences but rarely studied the substrate degradation direction of exolytic alginate lyases. In this study, we used a fluorescent labeling method to successfully determine that AlyPB2 removes monosaccharide residues one by one from the non-reducing end of alginate chains. On this basis, we established a novel method for sequencing alginate oligosaccharides by combining ${ }^{1} \mathrm{H}$ NMR analysis with exolytic lyase treatment for the first time. Compared to traditional 


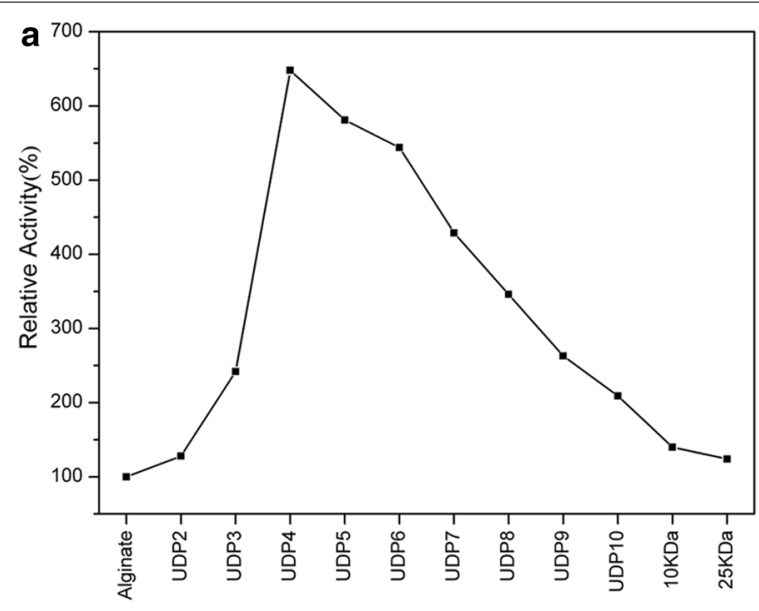

b $\quad \mu \mathrm{V}(\times 100,000)$

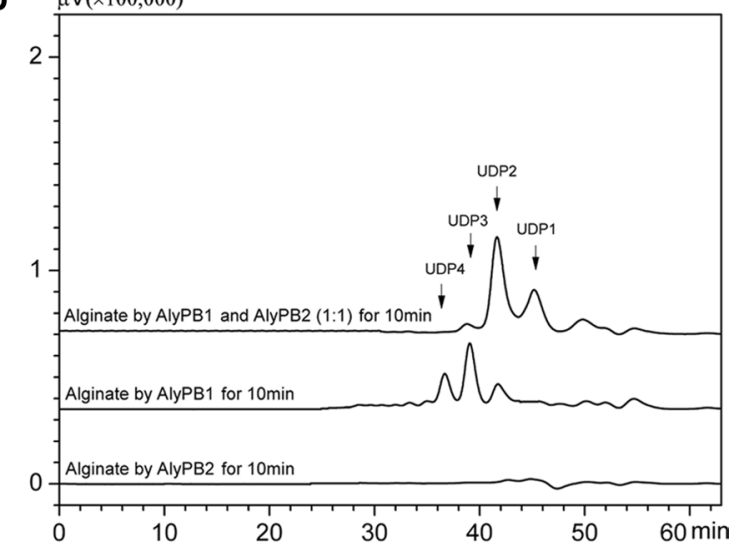

Fig. 8 Analysis for synergistic effect of AlyPB1 and AlyPB2. a The enzyme activities of exo-lyase AlyPB2 were determined using the alginate with different molecular sizes as substrates. Unsaturated oligosaccharide substrates UDP2-UDP10 were prepared from the partial digestion of alginate by endo-lyase AlyPB1. $10 \mathrm{kDa}$ and $25 \mathrm{kDa}$ alginate polysaccharide were prepared from acid hydrolysis of alginate. Data are shown as the percentage of the activity on alginate (100\%). b Alginate polysaccharide was treated with a mixture $(100 \mathrm{mU})$ of endo-lyase AlyPB1 and exo-lyase AlyPB2 with an activity ratio of $1: 1$ at $20^{\circ} \mathrm{C}$ for 10 min. By contrast, control was treated with only $100 \mathrm{mU}$ of AlyPB1 or AlyPB2 at the same reaction conditions. The resulting products were analysed by gel filtration as described above at a wavelength of $235 \mathrm{~nm}$. UDP1, UDP2, UDP3, and UDP4 represent unsaturated alginate oligosaccharides as mentioned above

analysis methods based on complex one- and two-dimensional NMR spectroscopy [51, 52], the method described in this paper makes compositional and structural analyses of larger alginate oligosaccharides ( $\geq$ UDP4) much easier to perform. The exact structures of the final products produced by many identified endolytic alginate lyases remain to be determined to completely elucidate their action patterns. By contrast, the structures of the main final products of alginate by AlyPB1 were completely determined using the novel method described in this paper. The results showed that UDP2 and UDP3 in the final products were mainly $\Delta G$ and $\Delta G G$, whereas all of UDP4 and UDP5 contained a reducing-end MM structure and more than $50 \% \mathrm{M}$ residues, which suggests that AlyPB1 preferentially digests the G-blocks in alginate chains to produce small $\Delta \mathrm{G}$ and $\Delta \mathrm{GG}$ structures but has difficulty cleaving $M$-rich domains, resulting in larger M-rich oligosaccharides ( $\geq$ UDP4) [53, 54].

In most cases, exolytic enzymes show very low enzymatic activity toward polysaccharides compared with those of endolytic enzymes, possibly because polysaccharides are too large to efficiently bind to exolytic enzymes. We are interested in whether exolytic enzymes preferentially degrade oligosaccharides and thus synergistically work with endolytic enzymes. However, this question has rarely been addressed in previous studies on alginate lyases. In this study, we found that the activity of AlyPB2 was substrate size-dependent and that its activity towards alginate oligosaccharides, especially tetrasaccharide chains, was much higher than that towards polysaccharides, similar to the activity of OalA from Vibrio splendidus 12B01 [28]. Furthermore, we found that compared to that when AlyPB2 was used alone, the conversion rate of alginate polysaccharides to unsaturated monosaccharides when AlyPB1 and AlyPB2 acted on alginate together was dramatically increased approximately sevenfold over a short time, demonstrating that the synergistic effect of AlyPB1 and AlyPB2 was quite remarkable.

By contrast, a detailed study on the synergistic mechanism of alginate lyases has rarely been reported. Gimpel et al. [31] used 21 different endo-/exo-lyase combinations to investigate the synergistic effect of different pairs, including 7 endo-lyases and 3 exo-lyases. However, they did not investigate the synergistic mechanism of these alginate lyases, while focused on only optimizing the conditions of the enzymatic reactions. Similarly, Wang et al. [30] studied the synergistic action conditions but not mechanism of an endo-lyase and an exo-lyase. Obviously, the synergistic mechanism of endolytic and exolytic alginate lyases has rarely been investigated in past studies. In our study, we elucidated the synergistic mechanism of AlyPB1 and AlyPB2, which is mainly based on the complementarity of their substrate-degrading properties, including their preference for M- and G-blocks and their substrate-size dependence. These findings are very important for the construction of a multi-enzyme system for the saccharification of alginate.

\section{Conclusions}

In conclusion, the identification of the two alginate lyases AlyPB1 and AlyPB2 from Photobacterium sp. FC615 provides not only two novel tool-type enzymes but also a good model for studying the synergistic effect 
of endolytic and exolytic lyases on the saccharification of alginate for biofuel production. Through studies of the enzymatic characteristics, substrate degradation patterns and structures of the final products, the synergistic mechanism of AlyPB1 and AlyPB2 was clearly elucidated, and a novel and simple method for alginate oligosaccharide sequencing using ${ }^{1} \mathrm{H}$ NMR spectroscopy and digestion with the exo-lyase AlyPB2 was established for the first time. It is worth emphasizing that compared to traditional methods based on complex one- and two-dimensional NMR spectroscopy, this novel method makes the structural analysis of alginate oligosaccharides larger than trimers easy to understand and carry out, which was proven in this study by the identification of the exact structures of oligosaccharide products generated by AlyPB1. In fact, the sequences of complex alginate oligosaccharides such as tetra- and pentasaccharides produced by most alginate lyases have rarely been sequenced in past studies, severely hindering further studies on related enzymes and their products. We believe that our method will be a powerful solution to this important issue, especially for more complex alginate oligosaccharides obtained from enzymatic, chemical or physical methods. In summary, this research will provide important theoretical and technical support for synergistic degradation as well as structure-function studies of alginate based on alginate lyases.

\section{Abbreviations}

$\triangle$ : 4-Deoxy-L-erythro-5-hexoseulose uronic acid; TPC: 2,4,5,6-Tetrahydroxytetrahydro-2H-pyran-2-carboxylic acid; DP: Degree of polymerization; G: Guluronate; M: Mannuronate; PolyG: Polyguluronate; PolyM: Polymannuronate; SDS-PAGE: Sodium dodecyl sulfate polyacrylamide gel electrophoresis; HPLC: High-performance liquid chromatography; NMR: Nuclear magnetic resonance; PL family: Polysaccharide lyase family; UDP1: Unsaturated monosaccharide; UDP2: Unsaturated disaccharide; UDP3: Unsaturated trisaccharide; UDP4: Unsaturated tetrasaccharide; UDP5: Unsaturated pentasaccharide; UDP6: Unsaturated hexasaccharide; DP5: Saturated alginate pentasaccharide.

\section{Author agreements}

All authors agree to publish this article.

\section{Statement of informed consent}

No informed consent, and human or animal rights applicable.

\section{Authors' contributions}

DRL designed the study under the guidance of FCL and WJH. Funding was secured by FCL and WJH. DRL and QDZ drafted and corrected the manuscript. DRL, QDZ, SMW, JWG, RMJ and NHH carried out the experiments, collected and analysed data. All authors read and approved the final manuscript.

\section{Funding and acknowledgements}

The work was supported by the National Natural Science Foundation of China (Grant Nos. 31570071, 31971201 and 31800665), the Science and Technology Development Project of Shandong Province (Grant Nos. 2018 GSF121002 and 2018GHY115036), the Natural Science Foundation of Shandong Province (Grant Nos. ZR2018BC013 and ZR2019MD038), and the Taishan Industry Leading Talents Program of Shandong Province (Grant No. tscy20160311).
Availability of data and materials

Not applicable.

Ethics approval and consent to participate

Not applicable.

\section{Consent for publication}

Not applicable.

\section{Competing interests}

The authors declare that they have no competing interests.

Received: 3 July 2019 Accepted: 24 October 2019

Published online: 04 November 2019

\section{References}

1. MacDonald LC, Weiler EB, Berger BW. Engineering broad-spectrum digestion of polyuronides from an exolytic polysaccharide lyase. Biotechnol Biofuels. 2016;9(1):43.

2. Jagadevan S, Banerjee A, Banerjee C, Guria C, Tiwari R, Baweja M, Shukla P. Recent developments in synthetic biology and metabolic engineering in microalgae towards biofuel production. Biotechnol Biofuels. 2018:11:185.

3. Banerjee A, Banerjee C, Negi S, Chang JS, Shukla P. Improvements in algal lipid production: a systems biology and gene editing approach. Crit Rev Biotechnol. 2018;3:369-85.

4. Banerjee A, Kumar N, Varjani SJ, Guria C, Bandopadhyay R, Shukla P, Banerjee C. Computational modelling and prediction of microalgae growth focused towards improved lipid production. Biosynthetic technology and environmental challenges. Cham: Springer; 2017. p. 223-32.

5. Saini DK, Chakdar H, Pabbi S, Shukla P. Enhancing production of microalgal biopigments through metabolic and genetic engineering. Crit Rev Food Sci Nutr. 2019;1:1-15.

6. Saini DK, Pabbi S, Shukla P. Cyanobacterial pigments: perspectives and biotechnological approaches. Food Chem Toxicol. 2018;120:616-24.

7. Medipally SR, Yusoff FM, Banerjee S, Shariff M. Microalgae as sustainable renewable energy feedstock for biofuel production. Biomed Res Int. 2015:2015:519513.

8. Wargacki AJ, Leonard E, Win MN, Regitsky DD, Santos CN, Kim PB, Cooper SR, Raisner RM, Herman A, Sivitz AB, et al. An engineered microbial platform for direct biofuel production from brown macroalgae. Science. 2012;335(6066):308-13.

9. Pei XJ, Chang YG, Shen JJ. Cloning, expression and characterization of an endo-acting bifunctional alginate lyase of marine bacterium Wenyingzhuangia fucanilytica. Protein Expr Purif. 2019;154:44-51.

10. Maki H, Mori A, Fujiyama K, Kinoshita S, Yoshida T. Cloning, sequence analysis and expression in Escherichia coli of a gene encoding an alginate lyase from Pseudomonas sp. OS-ALG-9. J Gen Microbiol. 1993;139(5):987-93.

11. Haug A, Larsen B, Smidsrød O. Studies on the sequence of uronic acid residues in alginic acid. Acta Chem Scand. 1967;21:691-704.

12. Haug A, Larsen B. Quantitative determination of the uronic acid composition of alginate. Acta Chem Scand. 1962;16:1908-18.

13. Yu ZC, Zhu BW, Wang WX, Tan HD, Yin H. Characterization of a new oligoalginate lyase from marine bacterium Vibrio sp. Int J Biol Macromol. 2018;112:937-42.

14. Zhu BW, Ni F, Sun Y, Ning LM, Yao Z. Elucidation of degrading pattern and substrate recognition of a novel bifunctional alginate lyase from Flammeovirga sp. NJ-04 and its use for preparation alginate oligosaccharides. Biotechnol Biofuels. 2019;12:13.

15. Preiss J, Ashwell G. Alginic acid metabolism in bacteria. I. Enzymatic formation of unsaturated oligosaccharides and 4-deoxy-L-erythro-5-hexoseulose uronic acid. J Biol Chem. 1962;237:309-16.

16. Wang DM, Aarstad OA, Li J, McKee LS, Sætrom GI, Vyas A, Srivastava V, Aachmann FL, Bulone V, Hsieh YSY. Preparation of 4-deoxy-L-erythro5-hexoseulose uronic acid (DEH) and guluronic acid rich alginate using a unique exo-alginate lyase from Thalassotalea crassostreae. J Agric Food Chem. 2018;66(6):1435-43. 
17. Peng CE, Wang QB, Lu DR, Han WJ, Li FC. A novel bifunctional endolytic alginate lyase with variable alginate-degrading modes and versatile monosaccharide-producing properties. Front Microbiol. 2018;9(167):1-14.

18. Xu F, Dong F, Wang P, Cao HY, Li CY, Li PY, Pang XH, Zhang YZ, Chen XL. Novel molecular insights into the catalytic mechanism of marine bacterial alginate lyase AlyGC from polysaccharide lyase family 6 . J Biol Chem. 2017:292(11):4457-68.

19. Uchimura K, Miyazaki M, Nogi Y, Kobayashi T, Horikoshi K. Cloning and sequencing of alginate lyase genes from deep-sea strains of Vibrio and Agarivorans and characterization of a new Vibrio enzyme. Mar Biotechnol. 2010;12(5):526-33.

20. Zhu B, Yin H. Alginate lyase: review of major sources and classification, properties, structure-function analysis and applications. Bioengineered. 2015;6(3):125-31.

21. Lee SI, Choi SH, Lee EY, Kim HS. Molecular cloning, purification, and characterization of a novel polyMG-specific alginate lyase responsible for alginate MG block degradation in Stenotrophomas maltophilia KJ-2. Appl Microbiol Biotechnol. 2012;95(6):1643-53.

22. Cantarel BL, Coutinho PM, Rancurel C, Bernard T, Lombard V, Henrissat B. The carbohydrate-active enzymes database (CAZy): an expert resource for glycogenomics. Nucleic Acids Res. 2009;37:D233-8.

23. Badur AH, Jagtap SS, Yalamanchili G, Lee JK, Zhao HM, Rao CV. Alginate lyases from alginate-degrading Vibrio splendidus 12B01 are endolytic. Appl Environ Microbiol. 2015;81(5):1865-73.

24. Li SY, Wang LN, Chen XH, Zhao WW, Sun M, Han YT. Cloning, expression, and biochemical characterization of two new oligoalginate lyases with synergistic degradation capability. Mar Biotechnol. 2018;20(1):75-86.

25. Hashimoto W, Miyake O, Momma K, Kawai S, Murata K. Molecular identification of oligoalginate lyase of Sphingomonas sp. Strain A1 as one of the enzymes required for complete depolymerization of alginate. J Bacteriol. 2000;182(16):4572-7.

26. Miyake O, Hashimoto W, Murata K. An exotype alginate lyase in Sphingomonas sp. Al: overexpression in Escherichia coli, purification, and characterization of alginate lyase IV (A1-IV). Protein Expr Purif. 2003;29(1):33-41.

27. Ochiai A, Yamasaki M, Mikami B, Hashimoto W, Murata K. Crystal structure of exotype alginate lyase Atu3025 from Agrobacterium tumefaciens. J Biol Chem. 2010;285(32):24519-28.

28. Jagtap SS, Hehemann JH, Polz MF, Lee JK, Zhao H. Comparative biochemical characterization of three exolytic oligoalginate lyases from Vibrio splendidus reveals complementary substrate scope, temperature, and pH adaptations. Appl Environ Microbiol. 2014;80(14):4207-14.

29. Wang LN, Li SY, Yu WG, Gong QH. Cloning, overexpression and characterization of a new oligoalginate lyase from a marine bacterium, Shewanella sp. Biotechnol Lett. 2015;37(3):665-71.

30. Wang DM, Kim HT, Yun EJ, Kim DH, Park YC, Woo HC, Kim KH. Optimal production of 4-deoxy-L-erythro-5-hexoseulose uronic acid from alginate for brown macro algae saccharification by combining endo- and exo-type alginate lyases. Bioprocess Biosyst Eng. 2014;37(10):2105-11.

31. Gimpel JA, Ravanal MC, Salazar O, Lienqueo ME. Saccharification of brown macroalgae using an arsenal of recombinant alginate lyases: potential application in the biorefinery process. J Microbiol Biotechnol. 2018;28(10):1671-82.

32. Thomas F, Lundqvist LCE, Jam M, Jeudy A, Barbeyron T, Sandstöm C, Michel G, Czjzek M. Comparative characterization of two marine alginate lyases from Zobellia galactanivorans reveals distinct modes of action and exquisite adaptation to their natural substrate. J Biol Chem. 2013;288(32):23021-37.

33. Wang SM, Guan JW, Zhang QD, Chen XX, Li FC. Identification and signature sequences of bacterial $\triangle 4,5$ hexuronate-2-O-sulfatases. Front Microbiol. 2019;10:704.

34. Hall TA. BioEdit: a user-friendly biological sequence alignment editor and analysis program for Windows 95/98/NT. Nucl Acids Symp Ser. 1999;41(41):95-8.

35. Kumar S, Tamura K, Nei M. MEGA: molecular evolutionary genetics analysis software for microcomputers. Comput Appl Biosci. 1994;10(2):189-91.

36. Tamura K, Peterson D, Peterson N, Stecher G, Nei M, Kumar S. MEGA5: molecular evolutionary genetics analysis using maximum likelihood, evolutionary distance, and maximum parsimony methods. Mol Biol Evol. 2011;28(10):2731-9.

37. Sambrook J, Russell DW. SDS-polyacrylamide gel electrophoresis of proteins. Csh Protocols. 2006;2006(4):281-3.
38. Kinoshita A, Sugahara K. Microanalysis of glycosaminoglycan-derived oligosaccharides labeled with a fluorophore 2-aminobenzamide by high-performance liquid chromatography: application to disaccharide composition analysis and exosequencing of oligosaccharides. Anal Biochem. 1999;269(2):367-78.

39. Heyraud A, Gey C, Leonard C, Rochas C, Girond S, Kloareg B. NMR spectroscopy analysis of oligoguluronates and oligomannuronates prepared by acid or enzymatic hydrolysis of homopolymeric blocks of alginic acid. Application to the determination of the substrate specificity of Haliotis tuberculata alginate lyase. Carbohydr Res. 1996;289:11-23.

40. Brown BJ, Preston JF. L-Guluronan-specific alginate lyase from a marine bacterium associated with Sargassum. Carbohydr Res. 1991;211(1):91-102.

41. Kam N, Park YJ, Lee EY, Kim HS. Molecular identification of a polyM-specific alginate lyase from Pseudomonas sp. strain KS-408 for degradation of glycosidic linkages between two mannuronates or mannuronate and guluronate in alginate. Can J Microbiol. 2011;57:1032-41.

42. Lundqvist LC, Jam M, Barbeyron T, Czizek M, Sandström C. Substrate specificity of the recombinant alginate lyase from the marine bacteria Pseudomonas alginovora. Carbohydr Res. 2012;352:44-50.

43. Lyu QQ, Zhang KK, Shi YH, Li WH, Diao XT, Liu WZ. Structural insights into a novel $\mathrm{Ca}^{2+}$-independent PL-6 alginate lyase from Vibrio OU02 identify the possible subsites responsible for product distribution. Biochim Biophys Acta Gen Subj. 2019;1863(7):1167-76.

44. Li SY, Wang LN, Han F, Gong QH, Yu WG. Cloning and characterization of the first polysaccharide lyase family 6 oligoalginate lyase from marine Shewanella sp. Kz7. J Biol Chem. 2016;159(1):77-86.

45. Gao S, Zhang ZL, Li SY, Su H, Tang LY, Tan YL, Yu WG, Han F. Characterization of a new endo-type polysaccharide lyase (PL) family 6 alginate lyase with cold-adapted and metal ions-resisted property. Int J Biol Macromol. 2018;120(Pt A):729-35.

46. Ochiai A, Hashimoto W, Murata K. A biosystem for alginate metabolism in Agrobacterium tumefaciens strain C58: molecular identification of Atu3025 as an exotype family PL-15 alginate lyase. Res Microbiol. 2006;157(7):642-9.

47. Mori T, Takahashi M, Tanaka R, Miyake H, Shibata T, Chow S, Kuroda K, Ueda M, Takeyama H. Falsirhodobacter sp. alg1 harbors single homologs of endo and exo-type alginate lyases efficient for alginate depolymerization. PLOS ONE. 2016;11(5):e0155537.

48. Chen YJ, Dou WF, Li H, Shi JS, Xu ZH. The alginate lyase from Isoptericola halotolerans CGMCC 5336 as a new tool for the production of alginate oligosaccharides with guluronic acid as reducing end. Carbohydr Res. 2018:470:36-41.

49. Stephanopoulos $\mathrm{G}$. Challenges in engineering microbes for biofuels production. Science. 2007;315(5813):801-4.

50. Enquist-Newman M, Faust AME, Bravo DD, Santos CNS, Raisner RM, Hanel A, Sarvabhowman P, Le C, Regitsky DD, Cooper SR, Peereboom L, Clark A, Martinez Y, Goldsmith J, Cho MY, Donohoue PD, Luo L, Lamberson B, Tamrakar P, Kim EJ, Villari JL, Gill A, Tripathi SA, Karamchedu P, Paredes CJ, Rajgarhia V, Kotlar HK, Bailey RB, Miller DJ, Ohler NL, Swimmer C, Yoshikuni Y. Efficient ethanol production from brown macroalgaesugars by a synthetic yeast platform. Nature. 2014;505(7482):239-43.

51. Zhang ZQ, Yu GL, Guan HS, Zhao X, Du YG, Jiang XL. Preparation and structure elucidation of alginate oligosaccharides degraded by alginate lyase from Vibro sp. 510. Carbohydr Res. 2004;339(8):1475-81.

52. Natsume M, Kamo Y, Hirayama M, Adachi T. Isolation and characterization of alginate-derived oligosaccharides with root growth-promoting activities. Carbohydr Res. 1994;258:187-97.

53. Han WJ, Gu JY, Cheng YY, Liu HH, Li YZ, Li FC. Novel alginate lyase (Aly5) from a polysaccharide-degrading marine bacterium, Flammeovirga sp. strain MYO4: effects of module truncation on biochemical characteristics, alginate degradation patterns, and oligosaccharide-yielding properties. Appl Environ Microbiol. 2015;82(1):364-74.

54. Cheng YY, Wang DD, Gu JY, Li JG, Liu HH, Li FC, Han WJ. Biochemical characteristics and variable alginate-degrading modes of a novel bifunctional endolytic alginate lyase. Appl Environ Microbiol. 2017;83(23):e01608-17.

\section{Publisher's Note}

Springer Nature remains neutral with regard to jurisdictional claims in published maps and institutional affiliations. 